\title{
Translesion Synthesis: Insights into the Selection and Switching of DNA Polymerases
}

\author{
Linlin Zhao $^{1,2, *}$ and M. Todd Washington ${ }^{3}$ \\ 1 Department of Chemistry and Biochemistry, Central Michigan University, Mount Pleasant, MI 48859, USA \\ 2 Science of Advanced Materials Program, Central Michigan University, Mount Pleasant, MI 48859, USA \\ 3 Department of Biochemistry, Carver College of Medicine, University of Iowa, Iowa City, IA 52242, USA; \\ todd-washington@uiowa.edu \\ * Correspondence: linlin.zhao@cmich.edu; Tel.: +1-989-774-3252
}

Academic Editor: Eishi Noguchi

Received: 30 November 2016; Accepted: 4 January 2017; Published: 10 January 2017

\begin{abstract}
DNA replication is constantly challenged by DNA lesions, noncanonical DNA structures and difficult-to-replicate DNA sequences. Two major strategies to rescue a stalled replication fork and to ensure continuous DNA synthesis are: (1) template switching and recombination-dependent DNA synthesis; and (2) translesion synthesis (TLS) using specialized DNA polymerases to perform nucleotide incorporation opposite DNA lesions. The former pathway is mainly error-free, and the latter is error-prone and a major source of mutagenesis. An accepted model of translesion synthesis involves DNA polymerase switching steps between a replicative DNA polymerase and one or more TLS DNA polymerases. The mechanisms that govern the selection and exchange of specialized DNA polymerases for a given DNA lesion are not well understood. In this review, recent studies concerning the mechanisms of selection and switching of DNA polymerases in eukaryotic systems are summarized.
\end{abstract}

Keywords: DNA damage; DNA lesion bypass; DNA polymerase; genomic instability; mutagenesis; translesion synthesis

\section{Introduction}

DNA is susceptible to numerous endogenous and exogenous chemicals, producing a wide variety of DNA lesions. Unrepaired DNA lesions are potential sources of replication and transcription errors, replication fork arrest, and cell death, which together contribute to genomic instability and pathogenesis. Two strategies exist to counteract replication fork stalling. One involves template switching, in which the undamaged template from the sister chromatid is used for recombination-dependent DNA synthesis; this process is usually error-free. A second strategy is to use one or more of the translesion synthesis (TLS) DNA polymerases (pols) to accomplish nucleotide incorporation opposite and past the DNA lesion before a replicative DNA polymerase (pol $\varepsilon$ or pol $\delta$ in eukaryotes) resumes its function. This process-which is intrinsically error-prone-is a major source of DNA damage-induced mutagenesis [1].

Genetic studies in the 1970s showed that mutations in the UV nonmutable (umu) locus in Escherichia coli (E. coli) [2,3] and the reversionless (REV) locus in Saccharomyces cerevisiae (S. cerevisiae) $[4,5]$ were associated with deficiencies in mutagenesis in these organisms upon treatment with DNA-damaging agents. Around the same time, cells from patients with a variant form of a cancer predisposition syndrome xeroderma pigmentosum (XP-V) were found to be deficient in synthesizing daughter DNA strands after UV irradiation [6]. It was not until the 1990s that the products of these and related genes were purified and biochemically characterized. The product of the yeast REV1 gene was found to be a dCMP transferase [7], and the product of the yeast REV3 gene was shown to be 
the catalytic subunit of pol $\zeta$, which is able to bypass a common UV-induced cyclobutane pyrimidine dimer (CPD) DNA lesion with low efficiency [8]. In 1999, the yeast Rad30 protein was shown to be able to replicate past a thymine-thymine CPD as efficiently and accurately as with undamaged thymines [9]. Shortly after, defects in the human gene encoding Rad30 was shown to cause the XP-V syndrome $[10,11]$. By 2000 , the arsenal of TLS polymerases had expanded rapidly with the discovery of E. coli pol IV (DinB) [12] and pol V (UmuC) [13,14], pol ı (a second human ortholog of Rad30) [15-18], and pol $\mathrm{\kappa}$ (a human ortholog of E. coli DinB) [19-22]. These findings led to the realization that TLS is a conserved process from bacteria to humans [23], which involves a large family of proteins, known as TLS DNA polymerases.

Today, 17 human DNA polymerases have been purified and biochemically characterized, and these proteins are classified into A, B, X, Y, and AEP (archaeo-eukaryotic primase superfamily) families according to their sequence homology and structural similarities [24-26]. The best-characterized Y-family DNA polymerases include pol $\eta$, pol ı, pol k, and Rev1, which, together with B-family enzyme pol $\zeta$, are the principle TLS pols in humans. Pols of A and X families also have TLS activities and contribute to mutagenesis in DNA repair pathways such as base excision repair and non-homologous end joining (NHEJ) [27]. The most recently discovered DNA polymerase/primase PrimPol (AEP superfamily) has the capability of bypassing a number of DNA lesions [26,28-31]. More importantly, PrimPol has primase activity that can perform de novo DNA synthesis using deoxyribonucleotide triphosphates (dNTPs), which is important for replication re-start downstream of a stalled fork [32-35]. Nowadays, the understanding of TLS polymerases has evolved from their conventional lesion bypass activities to myriad roles in organismal fitness and disease, such as to increase the diversity of the immunoglobulin gene during hypermutation, to overcome secondary DNA structures during DNA copying, to participate in DNA repair, and to contribute to mutagenesis in tumors $[25,27,36,37]$.

Translesion synthesis is thought to occur via two non-mutually exclusive processes. One is for TLS pols to participate at a replication fork, and the other is to fill post-replicative gaps [38]. The first process involves several polymerase-switching processes, including dissociation of a stalled replicative polymerase from the replication fork, binding of one or two TLS polymerases to the replication terminus for nucleotide insertion and extension, and eventually displacement of TLS pols with a replicative polymerase downstream of the DNA lesion [38,39]. The latter pathway requires fewer switching events. A major unanswered question is how polymerase switching occurs at the replication factories (reviewed in [40-42]). Deciphering the mechanisms of the polymerase exchange is not only fundamental for the understanding of translesion synthesis, but also important for the development of chemotherapy to control TLS activities $[25,38,43]$. This is because many cancer chemotherapies work by damaging DNA, and inhibiting TLS pols that affect DNA repair capability holds promise for improving responses to treatments [25,43]. This review aims to summarize recent studies on the mechanistic aspects of TLS in eukaryotic systems. For detailed discussions on the biochemical properties, regulation, and functions of TLS DNA polymerases, please see these excellent reviews $[24,27,38,44-46]$. Readers interested in TLS in bacteria are referred to the following reviews $[42,47]$.

\section{Selection and Switching of Specialized DNA Polymerases}

DNA is susceptible to a variety of chemicals from endogenous and exogenous sources, which generates up to 100,000 DNA lesions per cell each day [48]. Selection of the most appropriate specialized DNA polymerase to bypass a given lesion is dictated by a number of possible factors. One obvious factor is the identity of DNA lesions. A second potential factor is the interactions of specialized polymerases with hub proteins such as PCNA and Rev1. Other potential factors include the availability of TLS polymerases in the vicinity of stalled replication forks owing to cell cycle and transcription regulation or protein degradation. 


\subsection{Selection of the "Right" TLS Pol for Benzo[a]pyrene-Derived DNA Lesions: A Case Study}

In eukaryotes, various TLS polymerases have evolved to accommodate different types of DNA damage. When a polymerase is recruited to a stalled fork, it can only be used if it is able to accommodate the damaged primer-template in its active site and is able to catalyze the nucleotide-incorporation reaction [38]. Certain DNA modifications can be bypassed by replicative DNA polymerases [49,50], whereas bulky DNA lesions, such as carcinogen benzo[a]pyrene (BaP)-derived DNA damage, often require one or more TLS DNA polymerases to facilitate the fork progression [51]. Knowledge concerning cognate DNA lesions of each TLS pol has been reviewed [27,44,52]. TLS pols often act redundantly in the bypass of a given DNA lesion, and it is challenging to firmly identify the most biologically relevant DNA lesion for some pols. A few structurally distinct DNA lesions, such as cyclobutane pyrimidine dimer (CPD) and BaP-derived lesions, require specific polymerase activities [53,54]. Multiple factors including the chemistry of DNA lesion and DNA polymerase structure affect the selection of TLS pols. In the following section, DNA lesions derived from BaP, a prototypical carcinogen, will be used as an example to discuss how the chemistry of DNA lesions affects the enzymatic activities of DNA polymerases.

\subsubsection{BaP-Induced DNA Damage}

$\mathrm{BaP}$ is a ubiquitous environmental pollutant that exists in overcooked meat, vehicular exhaust, coal tar, and tobacco smoke. BaP is a Group 1 carcinogen classified by the International Agency for Research on Cancer (IARC), and has been associated with skin, lung, and colon cancers in humans $[55,56]$. The carcinogenicity of $\mathrm{BaP}$ is attributed in part to its ability to form the ultimate tumorigenic metabolites (+)-7 $\beta, 8 \alpha$-dihydroxy- $9 \alpha, 10 \alpha$-epoxy-7,8,9,10-tetrahydrobenzo[ $a]$ pyrene [7R,8S,9S,10R steric configuration; the most distant hydroxyl group is anti relative to the orientation of the epoxide group, and is hereinafter referred to as (+)-anti-BPDE] and (-)-7 $\alpha, 8 \beta$-dihydroxy-9 $\beta, 10 \beta$-epoxy7,8,9,10-tetrahydrobenzo[a]pyrene [7S,8R,9R,10S steric configuration; (-)-anti-BPDE] (Figure 1). (+)-anti-BPDE is more tumorigenic than its enantiomer (-)-anti-BPDE [57-59]. Both metabolites react with the $N^{2}$ exocyclic amino group of guanine (Figure 1 ) and to a lesser extent with the $N^{6}$ exocyclic amino groups of adenine and the $N^{4}$ exocyclic amino groups of cytosine to form DNA adducts $[60,61]$. Due to the carcinogenic potency, BPDE-derived DNA lesions are among the best-studied DNA lesions in terms of their toxicological mechanisms. Alternative bioactivation routes can convert BaP to radical cations that are reactive towards the C8 or N7 atoms of guanine and the N3 or N7 positions of adenine, some of which can form mutagenic apuridinic/apyrimidinic (AP) sites due to the unstable glycosidic linkage [62]. Other pathways involve biotransformation via aldo-keto reductase to yield reactive quinone-derived DNA adducts that are chemically labile or stable $[63,64]$. BaP-derived DNA lesions block DNA synthesis by replicative pols and induce mutagenic replication products via TLS. A prevalent mutation resulting from $\mathrm{BaP}$ exposure is a $\mathrm{G}$ to $\mathrm{T}$ transversion, a common mutation found in BaP-treated mammalian cells and the $p 53$ gene of lung cancers of smokers $[55,56]$. The local sequence context of BaP-induced DNA damage also plays a role in the resulting mutation pattern [65-68].

\subsubsection{Accurate Bypass of BaP-Derived DNA Lesions}

Major BPDE-derived DNA lesions include the stereoisomeric 2 -deoxyguanine (dG) adducts (+)-trans-anti-BPDE- $N^{2}-\mathrm{dG},(+)$-cis-anti-BPDE- $N^{2}-\mathrm{dG},(-)$-trans-anti-BPDE- $N^{2}-\mathrm{dG}$ and (-)-cis-antiBPDE- $N^{2}-\mathrm{dG}$ (Figure 1$)$, as well as the $2^{\prime}$-deoxyadenosine (dA) adducts (+)-trans-anti-BPDE- $N^{6}-\mathrm{dA}$, (+)-cis-anti-BPDE- $N^{6}-\mathrm{dA},(-)$-trans-anti-BPDE- $N^{6}-\mathrm{dA}$ and (-)-cis-anti-BPDE- $N^{6}-\mathrm{dA}$. These lesions are able to assume a variety of conformations depending on the local sequence context, as evidenced by solution nuclear magnetic resonance (NMR) structures (reviewed in [69] and references therein). Consequently, there is no universal TLS pol to bypass all lesions due to their structural diversity and the varying bypass capabilities of TLS pols. In addition, effects of the host cell and the local sequence context contribute to the varying degrees of bypass efficiencies and the resulting mutations [70]. Pol $\mathrm{k}$ 
is well known for its role in the accurate bypass of BPDE- $N^{2}-\mathrm{dG}$ DNA lesions. Pol $\kappa$ is capable of replicating past all four BPDE-derived $N^{2}-\mathrm{dG}$ lesions in a primarily error-free fashion in vitro and in vivo [22,71-74] and is protective against the mutagenic effects of $\mathrm{BaP}$ in cells [54,75]. However, pol $\mathrm{K}$ is unable to bypass (+)-trans-anti-BPDE- $N^{6}-\mathrm{dA}$ or (-)-trans-anti-BPDE- $N^{6}-\mathrm{dA}$ lesions [76], and these lesions are thought to contribute to the mutagenicity of low-dose BaP exposure [77-79]. The extent of the involvement of pol $\mathrm{k}$ in the accurate replication across the (+)-trans-anti-BPDE- $N^{2}-\mathrm{dG}$ lesion in cells remains controversial, mostly likely due to the different sequences and cell lines used in respective laboratories. Using a quantitative bypass assay, Avkin et al. demonstrated that approximately $60 \%$ of the (+)-trans-anti-BPDE- $N^{2}$-dG adducts require pol $\kappa$ for accurate bypass [75]. On the other hand, Hashimoto et al. showed that the error-free products account for less than $10 \%$ of total TLS products with the same DNA lesion in mouse embryonic fibroblasts [80]. Pol $\iota$, which is the least accurate TLS pol, is known for preferentially misincorporating T opposite unmodified G [81]. Interestingly, in vitro pol $\iota$ incorporates a correct nucleotide opposite stereoisomeric BPDE- $N^{2}$-dA adducts, although it is unable to insert nucleotides opposite BPDE- $N^{2}-\mathrm{dG}$ adducts or to extend the primer beyond the lesion $[76,82]$. Further experiments are needed to confirm the biological significance of this particular bypass activity of pol $\iota$.

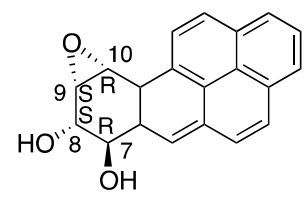

(+)-anti-BPDE

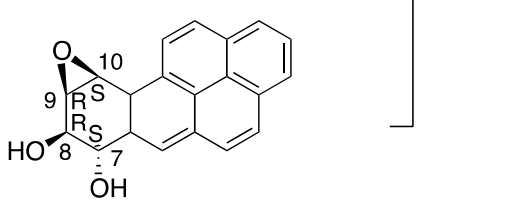

$(-)-$ anti-BPDE

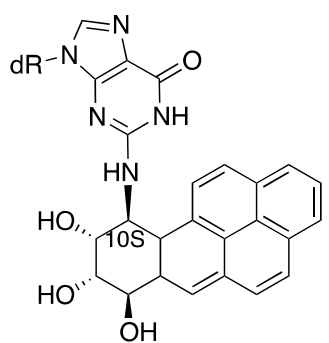

(+)-trans-anti-BPDE-N2-dG

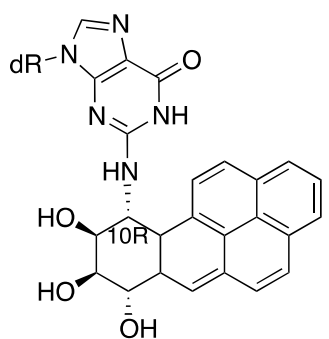

(-)-trans-anti-BPDE-N2-dG

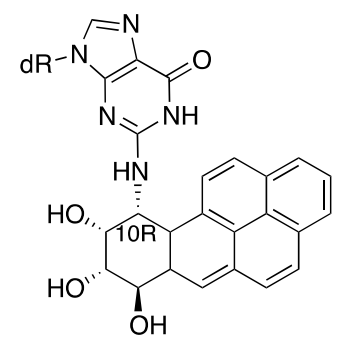

(+)-cis-anti-BPDE-N²-dG

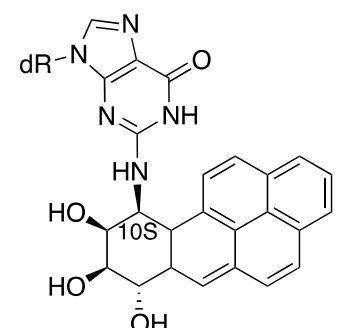

(-)-cis-anti-BPDE-N²-dG

Figure 1. Structures of stereoisomers of BPDE-derived $N^{2}$-dG DNA adducts.

A recent X-ray crystal structure of pol k:(+)-trans-anti-BPDE- $N^{2}$-dG-DNA:dCTP (pol k-BPDE) complex has provided insights into why pol $k$ is adept at bypassing bulky BPDE-induced DNA lesions [83]. The overall structure of pol k-BPDE closely resembles the structure of a pol $\kappa$ complex with an unmodified DNA substrate, indicating that pol $\kappa$ accommodates the (+)-trans-anti-BPDE- $N^{2}-\mathrm{dG}$ lesion at the active site (Figure 2A,B). The BPDE-adduced substrate adopts a standard B-form of DNA, and the BPDE- $N^{2}-\mathrm{dG}$ adduct retains the anti conformation. The BPDE ring is positioned in the minor groove and forms an additional H-bond with the incoming dCTP (Figure 2C). The BPDE ring points towards the $5^{\prime}$-end of the template strand, consistent with the solution NMR structures of DNA containing BPDE-derived dG lesions $[84,85]$. This conformation of the adduct is accommodated by an open DNA binding cleft in pol $\kappa$ (Figure 2D), which is not found in pol $\eta$ or pol ı. Modeling this conformation of the BPDE-adduced DNA into the structures of pol $\eta$ (Figure 2E) and pol $\iota$ (Figure 2F) results in steric clash with both pols. In addition, the unique $\mathrm{N}$-clasp domain of pol $\mathrm{\kappa}$ (not found in other 
Y-family TLS pols) supports an open conformation of the protein and stabilizes the single-stranded template for the efficient and error-free bypass of BPDE-dG DNA lesions [83].

A

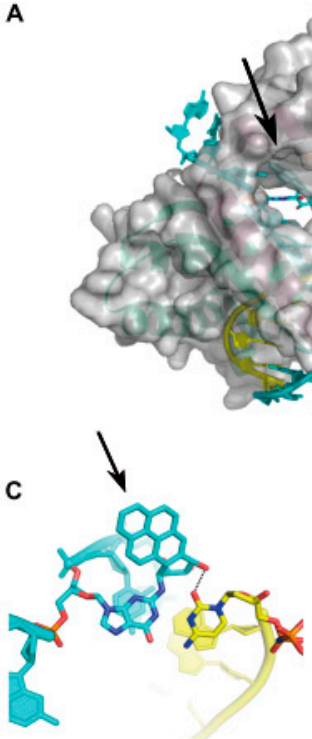

B

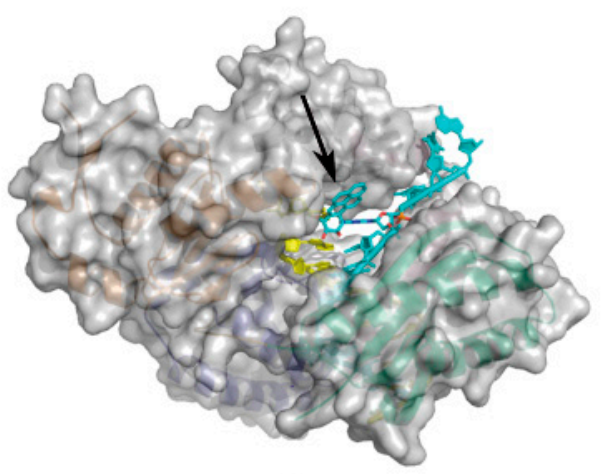

$E$

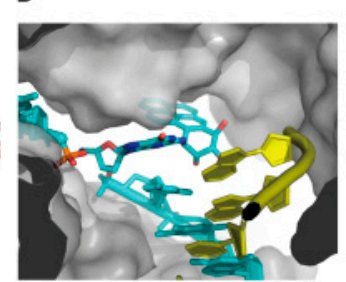

$\mathbf{F}$

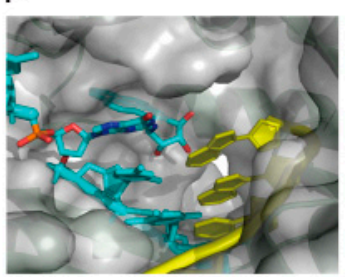

Figure 2. The structures of DNA polymerase complexes with a BPDE-dG lesion-containing duplex. The adducted template is shown in cyan, and the primer and incoming dCTP are shown in yellow. The black arrows are pointing at the BPDE ring. (A,B) Different views of the X-ray crystal structure of pol $\kappa:(+)$-trans-dG- $N^{2}$-BPDE-DNA:dCTP (pol к-BPDE) complex (PDB: 4U7C). The major groove of DNA is facing the viewer in (A); and the minor groove of DNA is facing the viewer in (B). (C) Base pairing of (+)-trans-dG- $N^{2}$-BPDE lesion and the incoming dCTP at the active site of pol $\mathrm{\kappa}$. An additional hydrogen bond formed between a hydroxyl group of BPDE and the $\mathrm{O}_{2}$ atom of cytidine is shown with a dashed line. (D) Zoomed-in view of pol $\mathrm{k}$ accommodating the BPDE ring in an open DNA binding cleft. (E) Structural model of pol ı (PDB: 4FS2) with an adducted substrate. The conformation of the DNA is adopted from the pol $\kappa-B P D E$ structure. (F) Structural model of pol $\eta$ (PDB: 3MR2) with an adducted substrate. The conformation of the DNA is from the pol k-BPDE structure. For simplicity, the incoming dCTP is omitted in (D-F).

The fact that pol $\iota$ is able to incorporate the correct dTTP opposite BPDE- $N^{6}-\mathrm{dA}$ DNA lesions in vitro suggests that pol $\iota$ can accommodate certain conformers of BPDE- $N^{6}-\mathrm{dA}$ DNA lesions at the active site. Although a ternary structure of pol ı with the BPDE- $N^{6}-\mathrm{dA}$ lesion and an incoming nucleotide is unavailable, molecular dynamics simulations have demonstrated that a BPDE- $N^{6}-\mathrm{dA}$ lesion assumes an anti or syn conformation at the active site of pol $\iota$ depending on the adjacent nucleotides forming a Watson-Crick or Hoogsteen base pair with the incoming dTTP, respectively [86]. The BPDE ring is positioned in the major groove due to the relatively narrow active site of pol $\iota$, and forms additional H-bonds with nearby nucleotides [86].

\subsubsection{Error-Prone Bypass of BaP-Derived DNA Lesions}

BaP-induced mutations are fueled at least in part by error-prone DNA replication across BPDE-derived DNA adducts [87]. More than 90\% of the bypass events across the (+)-trans-anti-BPDE- $N^{2}$-dG DNA lesion are error-prone in mouse embryonic fibroblasts [80]. For pol $\eta$, DNA synthesis is almost completely blocked by (-)-trans-anti-BPDE- $N^{6}-\mathrm{dA}$ adduct, whereas weak and error-prone bypass activities exist for both stereoisomeric BPDE- $N^{2}-\mathrm{dG}$ adducts and (+)-trans-anti-BPDE- $N^{6}-\mathrm{dA}$ adduct [76]. Using human XP-V fibroblasts that express a truncated and non-functional pol $\eta$ [9], Avkin et al. found that the bypass of the (+)-trans-anti-BPDE- $N^{2}-\mathrm{dG}-\mathrm{DNA}$ 
lesion is largely accurate and concluded that pol $\eta$ is not essential for TLS across this particular lesion with the template sequence they used [75]. On the other hand, pol $\zeta$ plays an important role in the mutagenic bypass of the (+)-trans-anti-BPDE- $N^{2}-\mathrm{dG}-\mathrm{DNA}$ lesion, which is likely due to its function as an extender DNA polymerase $[51,80]$. The importance of pol $\zeta$ in error-free bypass of BPDE-derived lesions remains controversial $[51,80]$. Rev1 is known for its deoxycytidyl transferase activity and its role as a scaffold protein to interact with other Y-family DNA polymerases [7,88-93]. Although Rev1 is capable of inserting dCTP opposite (+)-trans-anti-BPDE- $N^{2}-\mathrm{dG}$ and (-)-trans-anti-BPDE- $N^{2}-\mathrm{dG}$ DNA lesions in vitro [88], its role in error-free bypass seems to be nonessential in mouse cells [80]. Instead, the non-catalytic function of Rev1 is important for pol k-mediated BPDE resistance of mouse embryonic fibroblast cells [94], and for the erroneous bypass of the (+)-trans-anti-BPDE- $N^{2}-\mathrm{dG}$ lesion by pol $\zeta[80]$.

Together, it is apparent that the identity of BaP-derived DNA lesions drives the selection of TLS pols. Multiple factors, including the steric effects, tautomerization, the ability to form base pairs with the incoming nucleotide and local sequence context, seem to affect the selection of TLS pols. Apart from BaP-derived DNA lesions, a variety of DNA lesions have been assayed in vitro and in cellular experiments to identify the most biologically relevant TLS pol(s); however, in many cases, different TLS pols act redundantly during TLS [52], and it remains a challenge to generate a list of cognate lesions for each TLS pol. It seems logical for backup enzymes to exist for DNA replication and repair. The fact that a respective TLS pol has evolved to protect against the mutagenic effects of BPDE and CPD-derived DNA damage underscores the importance of these carcinogens.

\subsection{PCNA: An Interaction Hub for Many Partners}

PCNA is known for orchestrating a variety of components in DNA metabolism. PCNA was first discovered as an auxiliary protein that stimulates the activity of DNA polymerase $\delta[95,96]$, and was subsequently recognized for its remarkable abilities in coordinating multiple cellar processes such as unperturbed DNA replication, translesion synthesis, Okazaki fragment maturation, DNA repair, chromatin remodeling, and cell cycle regulation [97-100]. PCNA promotes the access of specialized pols to the replication factories through physical and functional interactions with these proteins. PCNA interacts with purified Y-family TLS pols and stimulates the catalytic efficiencies of these polymerases in vitro [101-104]. The understanding of the importance of these interactions in vivo was obtained primarily from nuclear focus-formation assays with DNA damaging reagent-treated cells ([105] and references therein). However, care should be taken in interpreting these results because the composition of these foci and whether they represent direct interactions are not known [105]. In this section, the biochemical basis of interactions between PCNA and different DNA polymerases is discussed.

\subsubsection{Interactions between PCNA and DNA Polymerases}

Eukaryotic PCNA comprises three identical subunits, and each subunit has two similarly folded domains joined by an interdomain connector loop (Figure 3A) [106,107]. The homotrimeric eukaryotic PCNA is assembled into a circular ring with a central hole that is wide enough to encircle the DNA and to allow diffusion of PCNA along the DNA [108]. The PCNA ring has one side facing the direction of DNA synthesis and the other side pointing away (hereinafter referred to as the front side and the back side of PCNA, respectively). The front side contains the C-terminus of each monomer and the interdomain-connecting loop. A hydrophobic pocket (Figure 3A) near the interdomain-connecting loop on the front side of each monomer serves as a platform to interact with DNA polymerases. In vitro, interactions between PCNA and purified TLS pols (e.g., human pol $\eta$, pol $\iota$ and pol $\kappa$ ) stimulate the catalytic efficiencies of these polymerases with unmodified and damaged DNA substrates via lowering the $K_{\mathrm{m}}$ of the incoming nucleotide [101-104]. Pol $\eta$ and pol ı, but not pol $\kappa$, have elevated processivity in the presence of PCNA, replication factor C (RFC) and replication protein A (RPA) [101-104]. Pol $\zeta$ is stimulated by PCNA with lesion-bearing DNA, but not with unmodified substrates $[109,110]$. 
PCNA stimulates the catalytic efficiency of Rev1 and does so to a greater extent when the PCNA is monoubiquitinated [111].
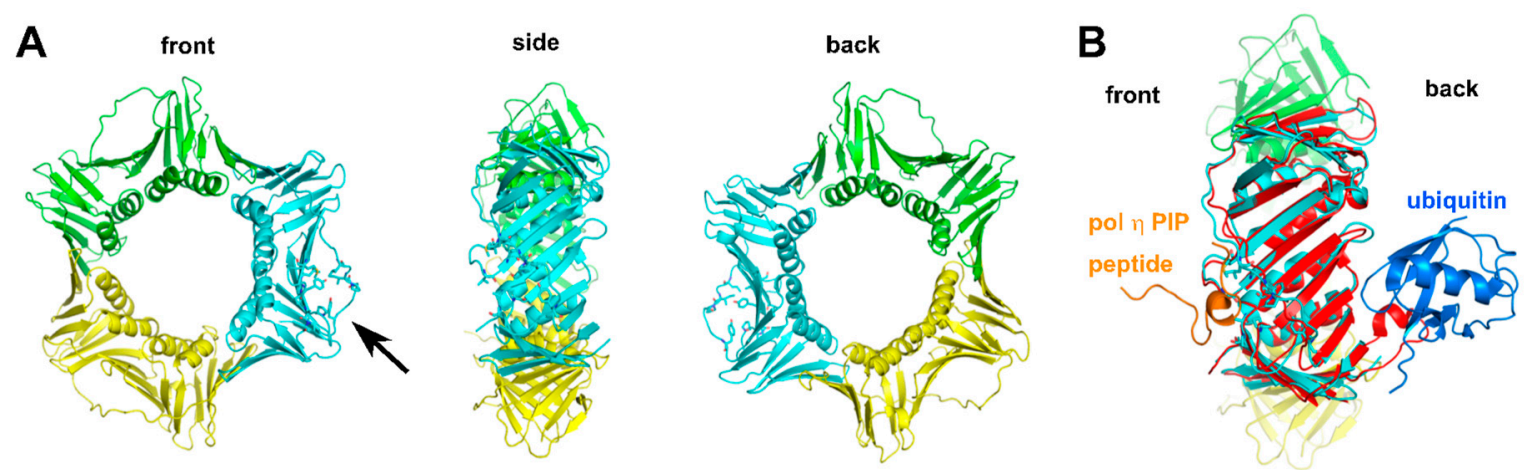

Figure 3. Structures of human PCNA and yeast ubiquitinated PCNA. (A) Front, side, and back views of human PCNA (PDB:2ZVK). Three subunits are shown in green, yellow, and cyan. In one subunit (cyan), amino acid residues surrounding the hydrophobic pocket near the interdomain-connecting loop are shown in stick. The black arrow is pointing at the hydrophobic pocket. For simplicity, the pol $\eta$ PIP peptide is omitted from the original crystal structure. (B) A subunit of yeast ubiquitinated PCNA (red; PDB:3L10) is superimposed with a subunit (cyan) of human PCNA (PDB:2ZVK). The pol $\eta$ PIP peptide (orange) interacts with the hydrophobic pocket on the front side of PCNA, and ubiquitin (blue) interacts with the back side of PCNA.

\subsubsection{Biochemical Basis of PCNA-Pol Interactions}

The interacting partners of PCNA in eukaryotes generally contain one or more PCNA-interacting protein (PIP) motifs. Based on the amino acid sequence of these motifs, PIPs are classified into canonical and non-canonical PIPs, which differ in their sequence and binding affinity for PCNA. Canonical PIPs, found in p21 WAF1/CIP1 [107], the p66 subunit of pol $\delta$ [112] and FEN1 [113], have a consensus sequence $\mathrm{Qxx}[\mathrm{L} / \mathrm{I} / \mathrm{M}] \mathrm{xx}[\mathrm{F} / \mathrm{Y}][\mathrm{F} / \mathrm{Y} / \mathrm{W}]$ featuring high-affinity interactions with PCNA. Non-canonical PIPs, on the other hand, have alternative residues at the first and last positions, lowering the binding affinity for PCNA relative to the consensus sequence. The difference in the binding affinities for PCNA potentially contributes to affinity-driven polymerase switching [98]. For example, the PIP peptide (QVSITGFF, canonical) of the p66 subunit of human pol $\delta$ has a higher affinity for PCNA relative to pol $\eta$ (MQTLESFE, non-canonical) [114]. Changing the first amino acid residue of the PIP peptide of pol $\eta$ to a glutamine (QQTLESFF) results in a four-fold increase in its affinity for PCNA [114]. The apparent dissociation constant $\left(K_{\mathrm{d}}\right)$ of human pol $\delta$, pol $\eta$, pol $\kappa$, and pol ı PIP peptides with PCNA are summarized in Table 1. Although affinity-driven competition has been proposed as a mechanism for polymerase switching, the molecular mechanism of this model remains to be studied in much detail. Rev1, on the other hand, has no PIP motifs, but interacts with PCNA through its N-terminal BRCA1 C-terminus (BRCT) domain $[115,116]$ and/or polymerase-associated domain (PAD) [117]. This interaction between the PAD domain of Rev1 and PCNA observed in yeast remains to be confirmed in vertebrates. Importantly, several recent studies have discovered non-conventional interacting partners of the PIP motif as well as the related Rev1-interacting region (RIR, see below). For example, yeast pol $\eta$ uses its PIP motif to interact with both PCNA and Rev1 [118], and human pol $\eta$ uses one of its RIR motifs to interact with Rev1 and pol $\delta$ [119]. In fact, the very notion of a PIP motif as a distinct entity has recently been questioned, and it has been proposed that these and other related motifs be renamed PIP-like motifs to better reflect their broader roles in the network of interacting proteins responsible for DNA replication and repair [120]. 
Table 1. Apparent dissociation constants $\left(K_{\mathrm{d}}\right)$ of DNA polymerase holoenzymes or PIP peptides with PCNA. Conserved amino acid residues relative to a consensus sequence are in bold. Italic cysteines indicate that these amino acid residues were included in addition to the native RIR peptide to facilitate the measurement.

\begin{tabular}{ccc}
\hline DNA Polymerase & Sequence & $K_{\mathbf{d}}(\mu \mathbf{M})$ \\
\hline pol $\delta$ PIP & ${ }_{451}$ GKANRQVSITGFFQRK & $16^{1}$ \\
\hline pol $\delta$ holoenzyme & & $<0.010^{2}$ \\
\hline pol $\eta$ PIP2 & $C_{694}$ KRPRPEGMQTLESFFKPLTH & $0.40^{3}$ \\
\hline pol $\eta$ holoenzyme & & $0.12^{4}$ \\
\hline pol $\kappa$ PIP + PLTH & $C_{856}$ IKPNNPKHTLDIFFKPLTH & $4.9^{3}$ \\
\hline pol ı PIP & $C_{419}$ AKKGLIDYYLMPSLST & $0.39^{3}$ \\
\hline
\end{tabular}

${ }^{1}$ Measured by isothermal titration calorimetry [112]; ${ }^{2}$ Estimated using a binding assay containing forked DNA-PCNA complex as substrate and pol $\delta$ as ligand. Values in ${ }^{2}$ and ${ }^{4}$ are from ref. [121]; ${ }^{3}$ Obtained from surface plasmon resonance (SPR) assays [114].

\subsubsection{Ubiquitination of PCNA}

Post-translational modifications of PCNA play an important role in DNA damage tolerance pathways $[97,98,122]$. Ubiquitination of PCNA, in particular, is known to participate in a variety of pathways during DNA replication and repair [122]. Ubiquitination of PCNA, mediated by the Rad6-Rad18 ubiquitination system, occurs in response to fork stalling near a lesion or an unusual DNA structure. Generally, the monoubiquitinated PCNA serves as an interacting platform for TLS DNA polymerases, whereas the polyubiquitinated PCNA is involved in error-free bypass via recombination-dependent pathways [122]. Ubiquitination of PCNA occurs primarily at K164 and to a lesser extent at other lysine residues [123,124]. One or two ubiquitin-binding motifs (UBMs; pol $\iota$ and Rev1) or ubiquitin-binding zinc-fingers (UBZs; pol $\eta$ and pol $\kappa$ ) are present in Y-family DNA polymerases [125], which increase the affinity of DNA polymerases for monoubiquitinated PCNA and potentially facilitate the recruitment of TLS pols. In S. cerevisiae, it is established that the monoubiquitination of PCNA is essential for optimal TLS and TLS polymerase switching. For example, in vitro studies using recombinant yeast enzymes show that both unmodified and monoubiquitinated PCNA stimulates the efficiencies of nucleotide incorporation by pol $\eta$ and REV1; however, a stronger stimulatory effect is observed when the PCNA is monoubiquitinated [111,126,127]. In addition, upon replication stalling, the exchange of yeast pol $\eta$ and pol $\delta$ occurs in the presence of monoubiquitinated PCNA but not with the unmodified PCNA [128]. In yeast cells, Rad6-mediated monoubiquitination of PCNA is required to activate TLS by pol $\eta[129,130]$.

On the contrary, in mammalian systems, whether a direct interaction between pol $\eta$ and ubiquitinated PCNA is required (or even occurs) during TLS remains controversial. In human cells, UBMs are needed for foci formation of Y-family polymerases and for physical interactions between polymerases and ubiquitinated PCNA $[125,131]$. However, as mentioned earlier, the foci formation should not be used to conclude that a direct interaction between pol $\eta$ and ubiquitinated PCNA is required (or even occurs) during TLS in mammalian systems. On the other hand, physical and specific interactions of pol $\eta$ with ubiquitinated PCNA have been demonstrated with co-immunoprecipitation using cell extracts $[132,133]$. While Acharya et al. reported that a direct binding of the UBZ domain of pol $\eta$ with ubiquitinated PCNA is not required during TLS [134], this conclusion has been questioned because the dispensability of the pol $\eta$ UBZ domain is thought to be due to an artificially increased PCNA expression [135]. Other in vivo evidence suggests ubiquitination of PCNA is in fact dispensable. For example, pol $\eta$ localizes into replication foci during unperturbed DNA replication [125] as well as upon treatment with UV irradiation $[133,136,137]$ independently of PCNA monoubiquitination. Hendel et al. have shown that the ubiquitination of PCNA is important, but not essential for TLS in mouse cells [138]. Using photobleaching techniques, Sabbioneda et al. have demonstrated that PCNA ubiquitination is not required for the pol $\eta$ foci formation, but increases the residence time of pol $\eta$ in foci in human cells [136]. In addition, studies from several laboratories have demonstrated that 
PCNA ubiquitination is dispensable during lesion bypass $[136,138,139]$, in which TLS pols may be recruited via interactions with Rev1 (discussed in Section 2.3) $[140,141]$. The interactions between TLS polymerases and PCNA are considered to be highly dynamic judging by the times of immobilization of pol $\eta$ and pol $\iota(100-200 \mathrm{~ms})$ upon DNA damage [136]. Therefore, it is proposed that pol $\eta$ transiently and continually probes the exposed DNA for suitable substrates [136]. Recently, using quantitative kinetic assays and a reconstituted lagging-strand replication system, Hedglin et al. have shown that the binding of pol $\eta$ to PCNA and pol $\eta$-catalyzed DNA synthesis occur without PCNA monoubiquitination, and that efficient exchange of pol $\eta$ with pol $\delta$ happens owing to the intrinsic DNA binding properties of these pols [121]. Additional studies are warranted to unequivocally determine the biological functions of PCNA ubiquitination in vivo.

\subsubsection{Structure of Monoubiquitinated PCNA}

The X-ray crystal structure of monoubiquitinated S. cerevisiae PCNA has provided additional insights into PCNA-polymerase interactions [126]. The expression of yeast monoubiquitinated PCNA is achieved by splitting the protein into two self-assembling polypeptides [126]. As shown in Figure 3B, the ubiquitin moiety uses its canonical hydrophobic surface to interact specifically but weakly with PCNA via electrostatic and hydrogen-bonding interactions. The attachment of ubiquitin does not alter the conformation of PCNA, suggesting that there is no or minimal conformational change of PCNA upon ubiquitin binding [126]. The ubiquitin molecule is located on the back side of PCNA, presumably leaving the hydrophobic pocket on the front side to interact with the PIPs of other DNA polymerases, which is consistent with a tool belt model of translesion synthesis. A PCNA tool belt is a structure with multiple TLS polymerases directly interacting with PCNA without directly interacting with one another. Based on the structure of ubiquitinated PCNA, it is proposed that when pol $\delta$ stalls at a DNA lesion, the ubiquitination of PCNA facilitates the recruitment of pol $\eta$ to the back side of PCNA [126]. The catalytic core of pol $\eta$ then displaces pol $\delta$ since it is connected to the C-terminus of pol $\eta$ by a long, flexible linker. A recent structural model derived from low-resolution single-particle electron microscopy suggests that pol $\eta$ can associate with the front face of the PCNA in the editing mode [142]. Additional structures of eukaryotic multi-protein complexes with DNA, PCNA and TLS pols are needed to fully understand how multiple TLS pols are coordinated.

\subsubsection{Additional Structural Motifs for Stabilizing PCNA-Pol Complexes}

In eukaryotes, B-family DNA polymerases include pol $\alpha$, pol $\delta$, pol $\varepsilon$, and pol $\zeta$. The former three polymerases are the major players responsible for the bulk of DNA synthesis, and pol $\zeta$ is a major error-prone DNA polymerase. In S. cerevisiae, pol $\delta$ is a three-subunit complex comprised of the catalytic subunit pol3 and accessory subunits pol31 and pol32. The pol $\delta$ holoenzyme is formed via interactions between pol31 and the C-terminal segment of pol3, and between pol32 and pol31 [143]. Subunits pol 31 and pol32 are also components of a four-subunit pol $\zeta 4$ (discussed in Section 2.4). In addition to the aforementioned structural motifs (PIPs and RIRs) that are important for protein-protein interactions, two conserved cysteine-rich metal-binding motifs (CysA and CysB) within the C-terminal segment of the catalytic subunits of all four B-family DNA polymerases are important for DNA replication and stabilizing multi-protein complexes in S. cerevisiae [144]. The Zn-binding motif, CysA of pol3 (the catalytic subunit of yeast pol $\delta$ ) plays a critical role in PCNA-pol $\delta$ complex formation, whereas [4Fe-4S]-binding motif CysB is imperative for the formation of a highly processive yeast pol $\delta$ holoenzyme [144]. Mutation of the conserved cysteine residues in the CysA motif significantly decreases the processivity of yeast pol $\delta$; processive DNA replication can be partially restored by adding wild-type pol $\delta$ into the system but cannot be restored by adding a mutant form of pol $\delta$ without the PIP motif on pol32 (pol32- $\triangle \mathrm{PIP}$ ). By contrast, fully proficient DNA replication was observed for mutant pol $\delta$ with pol32- $\Delta$ PIP. These results suggest that PIPs may be more relevant for recruiting pols to replication foci in the nucleus, whereas the conserved cysteine-rich metal-binding motifs are important for the formation and/or stability of the PCNA-pol $\delta$ complex in processive DNA 
replication [144]. This is consistent with the previously proposed two-stage recruitment model for TLS polymerases-first, to increase the local concentration of TLS pol(s) at the replication factories, and second, to load TLS pol(s) to the replication termini [38].

\subsection{Rev1: A Scaffold Protein}

$R E V 1$, along with $R E V 3$ and $R E V 7$, is among the first translesion synthesis DNA polymerase genes discovered in yeast mutagenesis experiments [4]. Rev1 is the most intriguing Y-family polymerase because of its deoxycytidyl transferase activity $[7,88]$ and its protein template-directed nucleotide incorporation [145]. Yeast genetic studies led to the suggestion that Rev1 has a "second function" separate from its catalytic activity [89]. Subsequent biochemical and cellular studies augmented this proposal by demonstrating that human and mouse Rev1 physically interacts with pol $\eta$, pol $\iota$, pol $\kappa$, and Rev7 (an accessory subunit of pol $\zeta$ ) [90-93], and that the catalytic-null mutant of Rev1 does not affect the levels of mutagenesis induced by DNA-damaging agents $[146,147]$.

\subsubsection{Interactions between Rev1 and Other Pols}

The interactions of Rev1 with its protein partners are critically dependent on its C-terminal domain (CTD) [90-92,147]. Rev1-interacting proteins contain RIRs that are centered around conserved phenylalanine residues (FF). These interacting proteins include B-family pol $\delta[110,148,149]$ and pol $\zeta$ [93,150]; Y-family pol $\iota$, pol $\kappa$, and pol $\eta$ [90-92,94,119]; base excision repair protein XRCC1 [151]; and yeast Rad5 (a multi-functional protein involved in template switching) [152]. Recent NMR and X-ray crystallographic data have provided a structural basis of the interactions between Rev1 and its partners. According to the solution NMR structures of the mouse Rev1 CTD-pol $\kappa$ RIR peptide complex and the human Rev1 CTD-pol $\eta$ RIR peptide complex [153,154], the overall core helix-bundle structure of the RIR-bound human Rev1 CTD is similar to that of the free Rev1 CTD (Figure 4A). Rev1 CTD folds into a four-helix bundle ( $\alpha 1-\alpha 4)$, mediated by a network of interacting residues from individual helices. A majority of these residues are conserved from yeast to human, which contribute to the stability of the CTD of Rev1 across species [154]. Six residues at the N-terminus of $\alpha 1$ helix fold into a structurally defined $\beta$-hairpin, and together with the shallow hydrophobic surface between $\alpha 1$ and $\alpha 2$, create a deep hydrophobic cavity for high-affinity binding with RIR peptides [153,154]. The disordered RIR peptides of pol $\eta$ and $k$ arrange into a three-turn $\alpha$-helix upon binding with Rev1 CTD. Two phenylalanine residues of the RIR peptides (of pol $\eta$, pol $\kappa$, and p66) interact with the hydrophobic cavity of Rev1 CTD (Figure 4B). These two conserved phenylalanine residues are essential for the formation of the protein complex as evidenced by mutational studies in yeast two-hybrid assays [94,153].
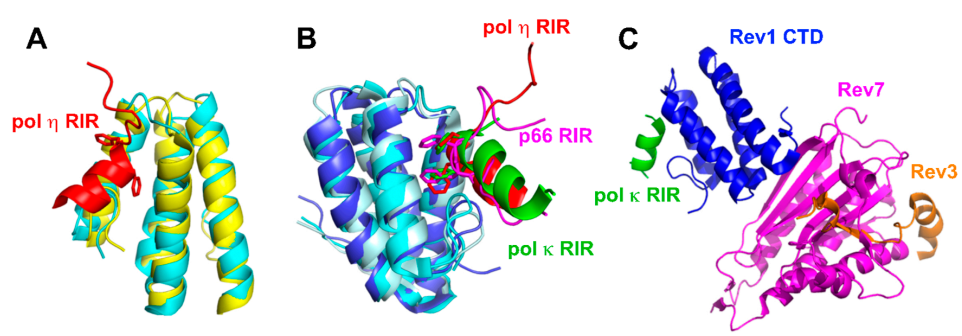

Figure 4. Interactions between Rev1 CTD and the RIR peptides or the interacting fragments of pol $\zeta$. (A) Superimposed structures of free human Rev1 CTD (yellow, PDB: 2LSY) and human pol $\eta$ RIR-bound Rev1 CTD (cyan, PDB: 2LSK). The pol $\eta$ RIR is in red with the side chains of the conserved phenylalanine residues shown in stick. (B) Superimposed structural complexes of mouse Rev1 CTD (blue; PDB:2LSJ) with the pol $\kappa$ RIR peptide (green), human Rev1 CTD (cyan; PDB:2LSK) with the pol $\eta$ RIR peptide (red) and human Rev1 CTD (pale cyan; PDB:2N1G) with the p66 (a subunit of pol $\zeta 4$ ) RIR peptide (magenta). Three RIR peptides interact with the same region of Rev1 CTD. The side chains of conserved phenylalanines are shown in stick. (C) Mouse Rev1 CTD in complex with Rev7, a fragment of Rev3 and the pol $\kappa$ RIR peptide (PDB: 4FJO). 


\subsubsection{Interactions between Rev1 and Pol $\zeta$}

Pol $\zeta$ is considered as an "extender polymerase" in the generally accepted two-step bypass mechanism in mammals [39,155]. In the first step, an "inserter" polymerase (e.g., pol $\eta$, pol เ or pol k) incorporates a nucleotide opposite the lesion, and in the second step an "extender" polymerase (e.g., pol $\zeta$ ) extends beyond the base pair that involved the lesion before a replicative polymerase takes over the DNA synthesis. It is well documented that the Rev7 subunit of human pol $\zeta$ interacts with Rev1 [93], and that the interaction is functionally important for translesion synthesis across a (6-4) thymine-thymine photoproduct [156]. Since the discovery of a four-subunit complex of pol $\zeta 4$ (Rev3-Rev7-p50-p66; p50 and p66 are also subunits of human pol $\delta$ ) [110,148,149], an additional RIR has been mapped on the p66 subunit of pol $\zeta$, which could also facilitate the formation of Rev1-pol $\zeta$ complex [150]. Together, interactions of Rev1 with both Rev7 and p66 potentially contribute to the recruitment of pol $\zeta$ via Rev1 and the functional linkage between pol $\zeta$ and Rev1.

\subsubsection{Coordination of Multiple Binding Partners by Rev1}

Recent X-ray crystallographic data have illuminated the molecular mechanisms of the interactions of Rev1 with a number of proteins. Wojtaszek et al. reported a crystal structure of mouse Rev1 CTD in complex with Rev7, an interacting fragment of Rev3 and the pol $\kappa$ RIR peptide (Figure 4C) [157]. Shortly after, Xie et al. reported the structure of a similar protein complex from humans [158]. In addition, Kikuchi et al. solved the crystal structure of a ternary complex containing the C-terminal domain of human Rev1 CTD, Rev7, and a Rev3 fragment [159]. Collectively, these studies have demonstrated that mammalian Rev1 CTD uses different binding regions to interact with Y-family pols and the Rev7 subunit of pol $\zeta$. As noted earlier, RIRs of pol $\eta$ and pol $\kappa$ target the same binding region of Rev1 CTD (Figure 4B), which involves the N-terminal $\beta$-hairpin, $\alpha 1$ and $\alpha 2$ helices, and $\alpha 1-\alpha 2$ loop [153,154]. On the other hand, Rev7 interacts with a distinct and non-overlapping region of CTD diagonal to the binding site of other Y-family pols (Figure 4C) [157,158], presumably to minimize the chance of steric clash between an "inserter" polymerase and pol $\zeta$ at the "insertion" step during Rev1/pol $\zeta$-dependent TLS [150]. Incidentally, the recently mapped RIR on the p66 subunit of pol $\zeta$ interacts with the same site on Rev1 CTD as RIRs of pol $\eta$ and pol $\kappa$ do (Figure 4B). Although the dissociation constants $\left(K_{\mathrm{d}}\right)$ of Rev1 with RIR peptides vary slightly based on the different techniques used (summarized in Table 2) $[94,150,151]$, RIRs of pol $\kappa$ and p66 bind to the Rev1 CTD approximately an order of magnitude stronger relative to RIRs of pol $\iota$ and pol $\eta$. The high affinity between p66 RIR and Rev1 CTD may be a contributing factor to the "inserter" to "extender" polymerase switching in a two-step Rev1/PolC-dependent TLS [150]. In summary, this body of work has provided structural mechanisms for the interactions between Rev1 and other TLS pols, and such information is important for designing inhibitors to disrupt these interactions [43].

Table 2. Apparent dissociation constants $\left(K_{\mathrm{d}}\right)$ of human p66 (a subunit of pol $\delta$ ), pol $\eta$, pol $\kappa$, and pol ı RIR peptides with human Rev1. Conserved phenylalanine residues are in bold.

\begin{tabular}{cccc}
\hline DNA Polymerase & Sequence & $\boldsymbol{K}_{\mathbf{d}}(\boldsymbol{\mu M})$ SPR & Fluorescence $^{3}$ \\
\hline p66 & 231 KGNMMSNFFGKAAMNK & $2.3^{1}$ & \\
pol $\eta$ & 524 QSTGTEPFFKQKSLLL & $13^{2}$ & 4.4 \\
pol $\kappa$ & 560 EMSHKKSFFDKKRSER & $7.6^{2}$ & \\
pol $\kappa$ & 560 EMSHKKSFFDKKRSER & $1.7^{1}$ & 0.28 \\
pol ı PIP & 539 ASRGVLSFFSKKQMQD & $69^{2}$ & 5.5 \\
\hline
\end{tabular}

$1,2 \overline{\text { Values are from references [94,150], respectively, and are obtained with surface plasma resonance (SPR) }}$ assays; ${ }^{3}$ Calculated from fluorescence titration assays [151].

\subsubsection{PCNA Tool Belts and Rev1 Bridges}

Based on the ways in which TLS polymerases interact with one another and with PCNA, it seems likely that multiple TLS polymerases and PCNA can form higher ordered complexes with different 
molecular architectures. For example, multiple TLS polymerases can directly interact with PCNA without directly interacting with one another, and form a PCNA tool belt. By contrast, Rev1 can serve as a bridging molecule to link PCNA (via BRCT and/or PAD domains) and another TLS polymerase (via CTD) without PCNA and this other TLS polymerase directly interacting. Such an arrangement is called a Rev1 bridge. Recently, single-molecule studies using yeast PCNA, pol $\eta$, and Rev1 have shown that both PCNA tool belts and Rev1 bridges form in approximately equal proportions [160]. Surprisingly, it was observed that these higher ordered complexes were dynamic, meaning that PCNA tool belts can switch to Rev1 bridges and vice versa without dissociation. The dynamic nature of these complexes likely permits rapid sampling of multiple TLS polymerases to find the one that is most appropriate for bypassing a given DNA lesion [160].

\subsubsection{Physiological Functions of Rev1-Mediated Protein Interactions}

The functional importance of Rev1-mediated protein-protein interactions appears to be polymerase- and lesion-specific. In the case of pol $\eta$-mediated CPD bypass, the formation of pol $\eta$ foci is dependent on the interactions between PCNA and pol $\eta$ (via PIPs and UBZ of pol $\eta$ ) $[125,131]$, but not on the interactions between Rev1 and pol $\eta$ (via RIRs) [161]. In keeping with these data, complementation with a variant form of pol $\eta$ with a $\mathrm{F}$ to A mutation in the RIRs resulted in a similar extent of suppression of UV-induced mutagenesis in XP-V fibroblasts relative to cells complemented with wild-type pol $\eta$ [162]. On the other hand, transient expression of wild-type pol $\kappa$ in pol $\kappa$-knockout mouse embryonic fibroblast cells restored the resistance to BPDE, whereas complementation with pol $\kappa$ bearing substitutions of phenylalanine residues in RIR fails to correct BPDE-sensitivity [94]. Together, Rev1 plays an important role in interacting with multiple TLS pols, but the biological significance of these interactions remains to be firmly established.

\subsection{Subunits Sharing between Pol $\delta$ and Pol $\zeta$}

\subsubsection{The Subunit Organization of $\mathrm{Pol} \zeta$}

In 2012, two groups discovered that yeast pol31 and pol32 proteins (previously recognized subunits of pol $\delta$ ) together with the Rev3-Rev7 complex of pol $\zeta$ form a four-subunit pol $\zeta 4[110,149]$. Similarly, p50 (POLD2) and p66 (POLD3) (human counterparts of yeast pol31 and pol32, respectively) are also components of pol $\zeta 4$ in humans [148]. Pol $\zeta 4$ has a higher catalytic activity than the minimally functional Rev3-Rev7 complex [110,149,163], and its activity is further enhanced in the presence of PCNA [110]. The pol $\zeta 4$ complex is organized via interactions between Rev3 and Rev7, Rev3 and pol31, pol31 and pol32, and pol32 and Rev7 [110,148,149,163]. In addition, pol32 is known to interact with PCNA, which is important for processive DNA replication by pol $\delta$ [164]. Analogous to the interaction between pol31 and the C-terminal segment of pol3, CysB of Rev3 (one of the two conserved cysteine-rich metal binding motifs) is essential for Rev3-pol31 interactions [110,148]. A structural model of yeast pol $\zeta 4$ based on electron microscopy reconstruction has been reported [165]. In this model, pol $\zeta 4$ adopts an elongated bilobal architecture, whereby Rev3 occupies a large lobe of the electron microscopy density map, and accessory subunits (Rev7, pol31, and pol32) locate in a small lobe connected to Rev3 via a longer amino acid linker.

\subsubsection{Switching between Pol $\delta$ and Pol $\zeta$}

Baranovskiy et al. proposed that the subunits sharing between pol $\delta$ and pol $\zeta$ may be a mechanism to facilitate polymerase switching [148]. Specifically, when pol $\delta$ stalls at a DNA lesion, p125 (the catalytic subunit of pol $\delta$ ) dissociates from p50-p66 for pol $\zeta$ to gain access to the replication fork. A caveat is that this proposal does not explain how pol $\zeta$ may operate on the leading strand (replicated by pol $\varepsilon$ ) [148]. Although this proposal remains to be explicitly tested, it provides a basis for further hypothesis generation and testing. Two possible pathways have been postulated for this polymerase switching model [166]. First, the p50-p66 complex remains attached to PCNA to interact 
with Rev3-Rev7 for pol $\zeta 4$ to gain access to the fork. Subunits p125 and p12 (an accessory subunit of pol $\delta$ ) can be degraded by proteolysis [167]. Second, p50-p66 dissociates from the fork together with p125, and a pre-assembled pol $\zeta 4$ complex is recruited for translesion synthesis. The latter pathway is augmented by the observation that p50-p66 complex binds to Rev3 fairly strongly, which withstands stringent washing with $1.0 \mathrm{M} \mathrm{NaCl}$ solution [163]. Interestingly, a recent proteomic analysis discovered significant changes of the levels of multiple components of pol $\delta$ when comparing wild-type cells to POLD3-deficient mouse cells, and that the levels of pol $\zeta$ constituents remain unchanged [168], which implies that p50-p66 may be preferentially associated with pol $\delta$ under normal conditions without DNA damage. The concentrations of p50 and p66 at the fork and their preferential association with pol $\delta$ or pol $\zeta$ under different cellular conditions remain to be determined. Remarkably, Stepchenkova et al. observed that a defect in the catalytic subunit of pol $\delta$ that affects the [4Fe- $4 \mathrm{~S}$ ] cluster binding leads to suppressed UV-induced mutagenesis and enhanced pol $\zeta$-dependent spontaneous mutagenesis in a yeast strain. On the basis of this finding, the authors proposed that the conserved [4Fe-4S] cluster in pol3 and Rev3 plays a role in pol $\delta$-pol $\zeta$ switching [169]. It is imperative to decipher the functional importance of Fe-S clusters in various aspects of DNA metabolism, including polymerase switching, and this question is being actively pursued in the field.

\subsection{Proteasomal Degradation of DNA Polymerases}

\subsubsection{Regulation of the Steady-State Levels of TLS Pols}

The error-prone nature of TLS polymerases means their access to the replication fork must be carefully regulated. Controlling the steady-state levels of DNA polymerases is a simple way to restrict enzymatic activities of low fidelity DNA polymerases. In E. coli, TLS pols are regulated via the global SOS response [42,170,171]. The levels of E. coli pol II, pol IV and pol V increase dramatically following LexA inactivation, which contributes to the polymerase switching ([42] and references therein). On the contrary, eukaryotes do not seem to use the overall expression level of TLS pols to respond to genotoxic stress [27], likely due to a larger number of TLS pols in eukaryotes compared to E. coli. Nonetheless, the steady-state levels of TLS pols are under strict regulation throughout the cell cycle in eukaryotes. In S. cerevisiae, the steady-state levels of both pol $\eta$ and Rev1 peak at G2/M phase relative to G1 phase and early $S$ phase, whereby a 3-fold increase is observed for pol $\eta$ and a 50-fold increase is observed for Rev1 [172-175]. In Schizosaccharomyces pombe, Rev1 exists at the highest level in G1 phase and is down-regulated at the entry of $S$ phase of the cell cycle [176]. The exact reason of such regulations remains unknown.

Contradictory results exist regarding whether the overexpression of TLS pols is associated with increased mutagenicity. While King et al. showed no mutagenic effects upon overproducing pol $\eta$ in diploid XP-V fibroblasts [177], other studies using yeast and mammalian systems demonstrated that overproduction and deletion of $R A D 30 / P O L H$ result in mutator phenotypes. For instance, overexpression of $P O L H$ in a multicopy episomal vector has been shown to be toxic to human cells [178]. Abnormal up-regulation of human pol $\eta$ through IRF1 transactivation leads to an elevated mutation frequency and carcinogenesis in human cells upon exposure to the alkylating agent $N$-methyl- $N^{\prime}$-nitro- $N$-nitrosoguanidine [179]. When RAD30 gene is compromised $[10,15,180]$ or overexpressed $[181,182]$ in S. cerevisiae, replication infidelity and genomic instability are observed. Similarly, overexpression of Rev1 confers sensitivity to cisplatin in fission yeast [176]. In addition, TLS pols are over-expressed in a number of cancers, which is considered to be a contributing factor to mutagenicity and resistance to chemotherapies [25,43].

\subsubsection{Proteasomal Degradation of TLS Pols}

TLS regulation can be achieved in part by proteasomal degradation orchestrated by posttranslational modifications. Posttranslational modifications with ubiquitin or ubiquitin-like modifiers play a critical role in the regulation of normal DNA replication and DNA damage tolerance 
pathways $[183,184]$. The attachment of ubiquitin to substrates is achieved via an enzymatic cascade by first attaching ubiquitin to an E1 ubiquitin-activating enzyme, then by transfer of ubiquitin to an E2 ubiquitin-conjugating enzyme, and by finally binding of E2 and substrate together with an E3 ubiquitin ligase, which completes the ubiquitin transfer from the E2 enzyme to the substrate [183]. There have been several reports of different E3 ligases being involved in the ubiquitination of pol $\eta$, which include Pirh2 (RING-H2 type E3 ligase) [185,186], mdm2 (murine double minute) [187], TRIP (human TNF receptor associated factor (TRAF)-interacting protein) in humans [188], and NOPO (homolog of human TRIP) in Drosophila [188]. For example, Pirh2 physically interacts with and monoubiquitinates human pol $\eta$ and is involved in the 20S proteasomal degradation of pol $\eta[185,186]$. Mdm2 physically interacts with pol $\eta$ in vivo and in vitro and facilitates pol $\eta$ degradation via ubiquitin-dependent proteolysis [187]. On the other hand, TRIP and NOPO E3 ligases promote the ubiquitination of pol $\eta$, and enhance the localization of pol $\eta$ in replication foci [188]. Apparently, unlike E. coli, eukaryotes prefer to regulate the local concentrations of pols at the fork by modulating the interactions of TLS pols with multiple binding partners. It should be kept in mind that the proteosomal degradation of TLS pols does not necessarily indicate their activities at the replication factories, and whether the degradation targets the soluble pool or chromatin-bound TLS pols remains to be elucidated. Nonetheless, a decrease in the concentration of a given TLS pol is likely to limit its access to the replication fork or to facilitate its removal after TLS.

\subsubsection{Protein Degradation Creates Binding Sites for TLS Pols}

CRL4 ${ }^{\text {Cdt2 }}$ (Cullin 4-RING Ligase (CRL4)-Ddb1-Cdt2) is an E3 ubiquitin ligase that targets PCNA binding partners for proteasomal degradation and is known as a master regulator for genomic stability [189]. CRL4 ${ }^{\mathrm{Cdt} 2}$ mediates the degradation of replication licensing factor Cdt1, which prevents DNA re-replication and genome instability [189]. In addition, CRL4 ${ }^{\mathrm{Cdt2}}$ facilitates the rapid degradation of Cdt1 after DNA damage [190,191]. In Caenorhabditis elegans, CRL4 ${ }^{\text {Cdt2 }}$ participates in the degradation of pol $\eta$ [192]; however, whether CRL4 ${ }^{\text {Cdt2 }}$ is involved in the degradation of pol $\eta$ in humans is yet to be tested. A number of CRL4 ${ }^{\mathrm{Cdt} 2}$ substrates including Cdt1 contain specialized PIP modules (PIP degrons), which are important for protein degradation $[189,193,194]$. Compared to a canonical PIP sequence, a PIP degron contains both a TD motif and a basic amino acid four residues downstream ([Q/N]xx $\phi \mathrm{TD}[\mathrm{F} / \mathrm{Y}][\mathrm{F} / \mathrm{Y}] \times x \times[\mathrm{R} / \mathrm{K}])$; the conserved TD motif confers stronger PCNA binding relative to canonical PIPs [193,194]. The conserved threonine residue within the Cdt1 PIP degron is important for interfering with pol $\eta$ foci formation after UV damage [195]. Importantly, CRL4 ${ }^{\text {Cdt2 }}$-mediated proteolysis facilitates pol $\eta$ and pol $\kappa$ focus formation after UV-induced DNA damage [195]. Thus, it is proposed that CRL4 ${ }^{\mathrm{Cdt} 2}$-mediated Cdt1 degradation unmasks the site on PCNA for the binding of TLS pols [195], although the molecular basis of this model remains to be established.

\subsubsection{Proteasomal Degradation of Pol $\delta$}

Protein degradation is an important means to regulate multi-subunit replicative DNA polymerase $\delta$, which potentially contributes to the displacement of pol $\delta$ at a stalled fork. Human pol $\delta$ is a four subunit complex (p125-p50-p66-p12, herein after referred to as pol 84 ) [196]. Collective studies by Lee and colleagues have shown that the p12 subunit of pol $\delta$ holoenzyme is subject to rapid proteolysis in human cells triggered by DNA damage or replication stress [167]. The loss of p12 leads to the formation of a trimeric form of pol $\delta 3$ (p125-p50-p66), which has impaired catalytic activities relative to pol $\delta 4[167,196]$. Detailed kinetic characterizations revealed that such a compromise in catalytic activity is mainly attributed to a decreased burst rate (a function of the rates of phosphodiester bond formation and conformational change) and a greater proofreading activity of pol $\delta 3$ [197]. As a result, pol 83 has an increased tendency to stall at DNA lesions, which may facilitate the exchange of TLS pols [198]. Interestingly, subsequent studies indicate that pol $\delta 3$ also functions during unperturbed DNA replication $[199,200]$, and the level of p12 subunit remains at a baseline level during unperturbed 
growth in unsynchronized cells [201]. As the authors pointed out, these studies measure the nuclear pool of p12 and pol $\delta 3$, and do not provide direct information on the assembly of pol $\delta$ at the replication fork [199]. Therefore, future studies are needed to fully understand the biological functions of pol $\delta 3$ and pol $\delta 4$, as well as the partition between the two. A recent study by Hedglin et al. demonstrates that human pol 84 maintains a loose association with PCNA when replicating DNA, and that pol $\delta 4$ holoenzyme is relatively unstable and rapidly dissociates upon stalling [202]. These authors suggest that on a lagging strand it may not be necessary for polymerases to engage in active polymerase switching in humans [128]. It is likely that p12 maintains a dynamic equilibrium between association and dissociation during lagging strand DNA synthesis, especially considering that pol $\delta$ has to continually replace pol $\alpha$ at primed sites [203,204].

\section{Concluding Remarks}

In summary, the understanding of the selection and switching of DNA polymerases has substantially advanced over the past decade. Nonetheless, questions remain regarding the molecular mechanisms of these processes. First, structures of multi-protein complexes with one or more specialized DNA polymerases, DNA, PCNA and a replicative DNA polymerase need to be solved. Such structures will be useful to further understand the coordination of multiple factors at the fork. Although protein complexes are often recalcitrant for crystallization, recent advances in cryo-electron microscopy holds promise for solving the problem. Second, the dynamics of multi-protein assembly remain poorly understood. Single molecule techniques together with rapid kinetics can potentially tackle this problem. Third, novel approaches are needed to systematically understand the coordination of multiple components during the selection and switching of DNA polymerases. Modern omics-based approaches in combination with bioinformatics may offer new solutions to this challenging task.

Acknowledgments: This work is supported in part by Central Michigan University start-up funds (to Linlin Zhao), US NIH R15 GM117522 (to Linlin Zhao), and US NIH R01 GM081433 (to M. Todd Washington). Authors are grateful to the anonymous reviewers who made constructive suggestions during revision of this manuscript, and to Benjamin Swarts for critically reading the manuscript.

Author Contributions: Linlin Zhao created the first draft; and Linlin Zhao and M. Todd Washington revised the paper.

Conflicts of Interest: The authors declare no conflict of interest. The funding sponsors had no role in the writing of the manuscript.

\section{References}

1. Hoeijmakers, J.H.J. Genome maintenance mechanisms for preventing cancer. Nature 2001, 411, 366-374. [CrossRef] [PubMed]

2. Kato, T.; Shinoura, Y. Isolation and characterization of mutants of Escherichia coli deficient in induction of mutations by ultraviolet light. Mol. Gen. Genet. 1977, 156, 121-131. [CrossRef] [PubMed]

3. Steinborn, G. Uvm mutants of Escherichia coli K 12 deficient in UV mutagenesis. Mol. Gen. Genet. 1978, 165, 87-93. [CrossRef] [PubMed]

4. Lemontt, J.F. Mutants of yeast defective in mutation induced by ultraviolet light. Genetics 1971, 68, 21-33. [PubMed]

5. Lawrence, C.W.; Christensen, R. UV mutagenesis in radiation-sensitive strains of yeast. Genetics 1976, 82, 207-232. [PubMed]

6. Lehmann, A.R.; Kirk-Bell, S.; Arlett, C.F.; Paterson, M.C.; Lohman, P.H.; de Weerd-Kastelein, E.A.; Bootsma, D. Xeroderma pigmentosum cells with normal levels of excision repair have a defect in DNA synthesis after UV-irradiation. Proc. Natl. Acad. Sci. USA 1975, 72, 219-223. [CrossRef] [PubMed]

7. Nelson, J.R.; Lawrence, C.W.; Hinkle, D.C. Deoxycytidyl transferase activity of yeast REV1 protein. Nature 1996, 382, 729-731. [CrossRef] [PubMed]

8. Nelson, J.R.; Lawrence, C.W.; Hinkle, D.C. Thymine-thymine dimer bypass by yeast DNA polymerase zeta. Science 1996, 272, 1646-1649. [CrossRef] [PubMed] 
9. Johnson, R.E.; Prakash, S.; Prakash, L. Efficient bypass of a thymine-thymine dimer by yeast DNA polymerase, Poln. Science 1999, 283, 1001-1004. [CrossRef] [PubMed]

10. Johnson, R.E.; Kondratick, C.M.; Prakash, S.; Prakash, L. hRAD30 mutations in the variant form of xeroderma pigmentosum. Science 1999, 285, 263-265. [CrossRef] [PubMed]

11. Masutani, C.; Kusumoto, R.; Yamada, A.; Dohmae, N.; Yokoi, M.; Yuasa, M.; Araki, M.; Iwai, S.; Takio, K.; Hanaoka, F. The XPV (xeroderma pigmentosum variant) gene encodes human DNA polymerase $\eta$. Nature 1999, 399, 700-704. [PubMed]

12. Wagner, J.; Gruz, P.; Kim, S.; Yamada, M.; Matsui, K.; Fuchs, R.P.P.; Nohmi, T. The dinB gene encodes a novel E. coli DNA polymerase, DNA pol IV, involved in mutagenesis. Mol. Cell 1999, 4, 281-286. [CrossRef]

13. Reuven, N.B.; Arad, G.; Maor-Shoshani, A.; Livneh, Z. The mutagenesis protein UmuC is a DNA polymerase activated by UmuD', RecA, and SSB and is specialized for translesion replication. J. Biol. Chem. 1999, 274, 31763-31766. [CrossRef] [PubMed]

14. Tang, M.; Shen, X.; Frank, E.G.; O’Donnell, M.; Woodgate, R.; Goodman, M.F. UmuD' 2C is an error-prone DNA polymerase, Escherichia coli pol V. Proc. Natl. Acad. Sci. USA 1999, 96, 8919-8924. [CrossRef] [PubMed]

15. McDonald, J.P.; Levine, A.S.; Woodgate, R. The Saccharomyces cerevisiae RAD30 gene, a homologue of Escherichia coli $\operatorname{din} B$ and $u m u C$, is DNA damage inducible and functions in a novel error-free postreplication repair mechanism. Genetics 1997, 147, 1557-1568. [PubMed]

16. Tissier, A.; McDonald, J.P.; Frank, E.G.; Woodgate, R. Pol ı, a remarkably error-prone human DNA polymerase. Genes Dev. 2000, 14, 1642-1650. [PubMed]

17. Johnson, R.E.; Washington, M.T.; Haracska, L.; Prakash, S.; Prakash, L. Eukaryotic polymerases ı and $\zeta$ act sequentially to bypass DNA lesions. Nature 2000, 406, 1015-1019. [PubMed]

18. Zhang, Y.; Yuan, F.; Wu, X.; Wang, Z. Preferential incorporation of G opposite template T by the low-fidelity human DNA polymerase ı. Mol. Cell. Biol. 2000, 20, 7099-7108. [CrossRef] [PubMed]

19. Ogi, T.; Kato, T.; Kato, T.; Ohmori, H. Mutation enhancement by DINB1, a mammalian homologue of the Escherichia coli mutagenesis protein DinB. Genes Cells 1999, 4, 607-618. [CrossRef] [PubMed]

20. Gerlach, V.L.; Aravind, L.; Gotway, G.; Schultz, R.A.; Koonin, E.V.; Friedberg, E.C. Human and mouse homologs of Escherichia coli DinB (DNA polymerase IV), members of the UmuC/DinB superfamily. Proc. Natl. Acad. Sci. USA 1999, 96, 11922-11927. [CrossRef] [PubMed]

21. Ohashi, E.; Ogi, T.; Kusumoto, R.; Iwai, S.; Masutani, C.; Hanaoka, F.; Ohmori, H. Error-prone bypass of certain DNA lesions by the human DNA polymerase k. Genes Dev. 2000, 14, 1589-1594. [PubMed]

22. Zhang, Y.; Yuan, F.; Wu, X.; Wang, M.; Rechkoblit, O.; Taylor, J.-S.; Geacintov, N.E.; Wang, Z. Error-free and error-prone lesion bypass by human DNA polymerase $\mathrm{k}$ in vitro. Nucleic Acids Res. 2000, 28, 4138-4146. [CrossRef] [PubMed]

23. Woodgate, R. A plethora of lesion-replicating DNA polymerases. Genes Dev. 1999, 13, 2191-2195. [CrossRef] [PubMed]

24. Hübscher, U.; Maga, G.; Spadari, S. Eukaryotic DNA polymerases. Annu. Rev. Biochem. 2002, 71, $133-163$. [CrossRef] [PubMed]

25. Lange, S.S.; Takata, K.; Wood, R.D. DNA polymerases and cancer. Nat. Rev. Cancer 2011, 11, $96-110$. [CrossRef] [PubMed]

26. Rudd, S.G.; Bianchi, J.; Doherty, A.J. PrimPol-A new polymerase on the block. Mol. Cell Oncol. 2014, 1, e960754. [CrossRef] [PubMed]

27. Sale, J.E. Translesion DNA synthesis and mutagenesis in eukaryotes. Cold Spring Harb. Perspect. Biol. 2013, 5, a012708. [CrossRef] [PubMed]

28. Bianchi, J.; Rudd, S.G.; Jozwiakowski, S.K.; Bailey, L.J.; Soura, V.; Taylor, E.; Stevanovic, I.; Green, A.J.; Stracker, T.H.; Lindsay, H.D. PrimPol bypasses UV photoproducts during eukaryotic chromosomal DNA replication. Mol. Cell 2013, 52, 566-573. [CrossRef] [PubMed]

29. García-Gómez, S.; Reyes, A.; Martínez-Jiménez, M.I.; Chocrón, E.S.; Mourón, S.; Terrados, G.; Powell, C.; Salido, E.; Méndez, J.; Holt, I.J. PrimPol, an archaic primase/polymerase operating in human cells. Mol. Cell 2013, 52, 541-553. [CrossRef] [PubMed]

30. Wan, L.; Lou, J.; Xia, Y.; Su, B.; Liu, T.; Cui, J.; Sun, Y.; Lou, H.; Huang, J. hPrimpol1/CCDC111 is a human DNA primase-polymerase required for the maintenance of genome integrity. EMBO Rep. 2013, 14, 1104-1112. [CrossRef] [PubMed] 
31. Zafar, M.K.; Ketkar, A.; Lodeiro, M.F.; Cameron, C.E.; Eoff, R.L. Kinetic analysis of human PrimPol DNA polymerase activity reveals a generally error-prone enzyme capable of accurately bypassing 7,8-dihydro-8-oxo-2'-deoxyguanosine. Biochemistry 2014, 53, 6584-6594. [CrossRef] [PubMed]

32. Mourón, S.; Rodriguez-Acebes, S.; Martínez-Jiménez, M.I.; García-Gómez, S.; Chocrón, S.; Blanco, L.; Méndez, J. Repriming of DNA synthesis at stalled replication forks by human PrimPol. Nat. Struct. Mol. Biol. 2013, 20, 1383-1389. [CrossRef] [PubMed]

33. Martínez-Jiménez, M.I.; García-Gómez, S.; Bebenek, K.; Sastre-Moreno, G.; Calvo, P.A.; Díaz-Talavera, A.; Kunkel, T.A.; Blanco, L. Alternative solutions and new scenarios for translesion DNA synthesis by human PrimPol. DNA Repair 2015, 29, 127-138. [CrossRef] [PubMed]

34. Schiavone, D.; Jozwiakowski, S.K.; Romanello, M.; Guilbaud, G.; Guilliam, T.A.; Bailey, L.J.; Sale, J.E.; Doherty, A.J. PrimPol is required for replicative tolerance of $\mathrm{G}$ quadruplexes in vertebrate cells. Mol. Cell 2016, 61, 161-169. [CrossRef] [PubMed]

35. Kobayashi, K.; Guilliam, T.A.; Tsuda, M.; Yamamoto, J.; Bailey, L.J.; Iwai, S.; Takeda, S.; Doherty, A.J.; Hirota, K. Repriming by PrimPol is critical for DNA replication restart downstream of lesions and chain-terminating nucleosides. Cell Cycle 2016, 15, 1997-2008. [CrossRef] [PubMed]

36. Jansen, J.G.; Tsaalbi-Shtylik, A.; de Wind, N. Roles of mutagenic translesion synthesis in mammalian genome stability, health and disease. DNA Repair 2015, 29, 56-64. [CrossRef] [PubMed]

37. Wickramasinghe, C.M.; Arzouk, H.; Frey, A.; Maiter, A.; Sale, J.E. Contributions of the specialised DNA polymerases to replication of structured DNA. DNA Repair 2015, 29, 83-90. [CrossRef] [PubMed]

38. Sale, J.E.; Lehmann, A.R.; Woodgate, R. Y-family DNA polymerases and their role in tolerance of cellular DNA damage. Nat. Rev. Mol. Cell Biol. 2012, 13, 141-152. [CrossRef] [PubMed]

39. Prakash, S.; Prakash, L. Translesion DNA synthesis in eukaryotes: A one-or two-polymerase affair. Genes Dev. 2002, 16, 1872-1883. [CrossRef] [PubMed]

40. Lehmann, A.R.; Niimi, A.; Ogi, T.; Brown, S.; Sabbioneda, S.; Wing, J.F.; Kannouche, P.L.; Green, C.M. Translesion synthesis: Y-family polymerases and the polymerase switch. DNA Repair 2007, 6, 891-899. [CrossRef] [PubMed]

41. Friedberg, E.C.; Lehmann, A.R.; Fuchs, R.P.P. Trading places: How do DNA polymerases switch during translesion DNA synthesis? Mol. Cell 2005, 18, 499-505. [CrossRef] [PubMed]

42. Sutton, M.D. Coordinating DNA polymerase traffic during high and low fidelity synthesis. BAA Protein Proteom. 2010, 1804, 1167-1179. [CrossRef] [PubMed]

43. Korzhnev, D.M.; Hadden, M.K. Targeting the translesion synthesis pathway for the development of anti-cancer chemotherapeutics. J. Med. Chem. 2016, 59, 9321-9336. [CrossRef] [PubMed]

44. Prakash, S.; Johnson, R.E.; Prakash, L. Eukaryotic translesion synthesis DNA polymerases: Specificity of structure and function. Annu. Rev. Biochem. 2005, 74, 317-353. [CrossRef] [PubMed]

45. Yang, W.; Woodgate, R. What a difference a decade makes: Insights into translesion DNA synthesis. Proc. Natl. Acad. Sci. USA 2007, 104, 15591-15598. [CrossRef] [PubMed]

46. Washington, M.T.; Carlson, K.D.; Freudenthal, B.D.; Pryor, J.M. Variations on a theme: Eukaryotic Y-family DNA polymerases. BAA Protein Proteom. 2010, 1804, 1113-1123. [CrossRef] [PubMed]

47. Goodman, M.F.; Woodgate, R. Translesion DNA polymerases. Cold Spring Harb. Perspect. Biol. 2013, 5, a010363. [CrossRef] [PubMed]

48. Hübscher, U.; Maga, G. DNA replication and repair bypass machines. Curr. Opin. Chem. Biol. 2011, 15, 627-635. [CrossRef] [PubMed]

49. Einolf, H.J.; Guengerich, F.P. Fidelity of nucleotide insertion at 8-oxo-7,8-dihydroguanine by mammalian DNA polymerase $\delta$ steady-state and pre-steady-state kinetic analysis. J. Biol. Chem. 2001, 276, 3764-3771. [CrossRef] [PubMed]

50. Hirota, K.; Tsuda, M.; Mohiuddin; Tsurimoto, T.; Cohen, I.S.; Livneh, Z.; Kobayashi, K.; Narita, T.; Nishihara, K.; Murai, J.; et al. In vivo evidence for translesion synthesis by the replicative DNA polymerase $\delta$. Nucleic Acids Res. 2016, 44, 7242-7250. [PubMed]

51. Shachar, S.; Ziv, O.; Avkin, S.; Adar, S.; Wittschieben, J.; Reißner, T.; Chaney, S.; Friedberg, E.C.; Wang, Z.; Carell, T.; et al. Two-polymerase mechanisms dictate error-free and error-prone translesion DNA synthesis in mammals. EMBO J. 2009, 28, 383-393. [CrossRef] [PubMed] 
52. Waters, L.S.; Minesinger, B.K.; Wiltrout, M.E.; D'Souza, S.; Woodruff, R.V.; Walker, G.C. Eukaryotic translesion polymerases and their roles and regulation in DNA damage tolerance. Microbiol. Mol. Biol. Rev. 2009, 73, 134-154. [CrossRef] [PubMed]

53. Matsuda, T.; Bebenek, K.; Masutani, C.; Hanaoka, F.; Kunkel, T.A. Low fidelity DNA synthesis by human DNA polymerase $\eta$. Nature 2000, 404, 1011-1013. [PubMed]

54. Ogi, T.; Shinkai, Y.; Tanaka, K.; Ohmori, H. Polk protects mammalian cells against the lethal and mutagenic effects of benzo[a]pyrene. Proc. Natl. Acad. Sci. USA 2002, 99, 15548-15553. [CrossRef]

55. Denissenko, M.F.; Pao, A.; Tang, M.-S.; Pfeifer, G.P. Preferential formation of benzo[a]pyrene adducts at lung cancer mutational hotspots in p53. Science 1996, 274, 430-432. [CrossRef] [PubMed]

56. Pfeifer, G.P.; Denissenko, M.F.; Olivier, M.; Tretyakova, N.; Hecht, S.S.; Hainaut, P. Tobacco smoke carcinogens, DNA damage and p53 mutations in smoking-associated cancers. Oncogene 2002, 21, 7435-7451. [CrossRef] [PubMed]

57. Slaga, T.J.; Bracken, W.J.; Gleason, G.; Levin, W.; Yagi, H.; Jerina, D.M.; Conney, A.H. Marked differences in the skin tumor-initiating activities of the optical enantiomers of the diastereomeric benzo[ $a]$ pyrene 7,8-diol-9,10-epoxides. Cancer Res. 1979, 39, 67-71. [PubMed]

58. Thakker, D.R.; Yagi, H.; Lu, A.Y.; Levin, W.; Conney, A.H. Metabolism of benzo[a]pyrene: Conversion of (+/-)-trans-7,8-dihydroxy-7,8-dihydrobenzo[a]pyrene to highly mutagenic 7,8-diol-9,10-epoxides. Proc. Natl. Acad. Sci. USA 1976, 73, 3381-3385. [CrossRef] [PubMed]

59. Kapitulnik, J.; Wislocki, P.G.; Levin, W.; Yagi, H.; Thakker, D.R.; Akagi, H.; Koreeda, M.; Jerina, D.M.; Conney, A.H. Marked differences in the carcinogenic activity of optically pure (+)-and (-)-trans7,8-dihydroxy-7,8-dihydrobenzo[a]pyrene in newborn mice. Cancer Res. 1978, 38, 2661-2665. [PubMed]

60. Straub, K.M.; Meehan, T.; Burlingame, A.L.; Calvin, M. Identification of the major adducts formed by reaction of benzo[a]pyrene diol epoxide with DNA in vitro. Proc. Natl. Acad. Sci. USA 1977, 74, 5285-5289. [CrossRef] [PubMed]

61. Cheng, S.C.; Hilton, B.D.; Roman, J.M.; Dipple, A. DNA adducts from carcinogenic and noncarcinogenic enantiomers of benzo[a]pyrenedihydrodiol epoxide. Chem. Res. Toxicol. 1989, 2, 334-340. [CrossRef] [PubMed]

62. Devanesan, P.D.; RamaKrishna, N.V.S.; Todorovic, R.; Rogan, E.G.; Cavalieri, E.L.; Jeong, H.; Jankowiak, R.; Small, G.J. Identification and quantitation of benzo[ $a$ ]pyrene-DNA adducts formed by rat liver microsomes in vitro. Chem. Res. Toxicol. 1992, 5, 302-309. [CrossRef] [PubMed]

63. McCoull, K.D.; Rindgen, D.; Blair, I.A.; Penning, T.M. Synthesis and characterization of polycyclic aromatic hydrocarbon $o$-quinone depurinating N7-guanine adducts. Chem. Res. Toxicol. 1999, 12, 237-246. [CrossRef] [PubMed]

64. Balu, N.; Padgett, W.T.; Lambert, G.R.; Swank, A.E.; Richard, A.M.; Nesnow, S. Identification and characterization of novel stable deoxyguanosine and deoxyadenosine adducts of benzo[a]pyrene-7, 8-quinone from reactions at physiological pH. Chem. Res. Toxicol. 2004, 17, 827-838. [CrossRef] [PubMed]

65. Shukla, R.; Geacintov, N.E.; Loechler, E.L. The major, $N^{2}$-dG adduct of (+)-anti-B[a]PDE induces G $\rightarrow$ A mutations in a 5'-AGA-3' sequence context. Carcinogenesis 1999, 20, 261-268. [CrossRef] [PubMed]

66. Seo, K.-Y.; Jelinsky, S.A.; Loechler, E.L. Factors that influence the mutagenic patterns of DNA adducts from chemical carcinogens. Mutat. Res. 2000, 463, 215-246. [CrossRef]

67. Chary, P.; Stone, M.P.; Lloyd, R.S. Sequence context modulation of polycyclic aromatic hydrocarbon-induced mutagenesis. Environ. Mol. Mutagen. 2013, 54, 652-658. [CrossRef] [PubMed]

68. Menzies, G.E.; Reed, S.H.; Brancale, A.; Lewis, P.D. Base damage, local sequence context and TP53 mutation hotspots: A molecular dynamics study of benzo[a]pyrene induced DNA distortion and mutability. Nucleic Acids Res. 2015, 43, 9133-9146. [CrossRef] [PubMed]

69. Geacintov, N.E.; Cosman, M.; Hingerty, B.E.; Amin, S.; Broyde, S.; Patel, D.J. NMR solution structures of stereoisomeric covalent polycyclic aromatic carcinogen-DNA adducts: Principles, patterns, and diversity. Chem. Res. Toxicol. 1997, 10, 111-146. [CrossRef] [PubMed]

70. Moriya, M.; Spiegel, S.; Fernandes, A.; Amin, S.; Liu, T.; Geacintov, N.; Grollman, A.P. Fidelity of translesional synthesis past benzo[ $a]$ pyrene diol epoxide-2'-deoxyguanosine DNA adducts: Marked effects of host cell, sequence context, and chirality. Biochemistry 1996, 35, 16646-16651. [CrossRef] [PubMed] 
71. Zhang, Y.; Wu, X.; Guo, D.; Rechkoblit, O.; Wang, Z. Activities of human DNA polymerase $\mathrm{k}$ in response to the major benzo[a]pyrene DNA adduct: Error-free lesion bypass and extension synthesis from opposite the lesion. DNA Repair 2002, 1, 559-569. [CrossRef]

72. Choi, J.-Y.; Angel, K.C.; Guengerich, F.P. Translesion synthesis across bulky N2-alkyl guanine DNA adducts by human DNA polymerase к. J. Biol. Chem. 2006, 281, 21062-21072. [CrossRef] [PubMed]

73. Suzuki, N.; Ohashi, E.; Kolbanovskiy, A.; Geacintov, N.E.; Grollman, A.P.; Ohmori, H.; Shibutani, S. Translesion synthesis by human DNA polymerase $\mathrm{k}$ on a DNA template containing a single stereoisomer of dG-(+)-or dG-(-)-anti-N²-BPDE (7,8-dihydroxy-anti-9,10-epoxy-7,8,9,10-tetrahydrobenzo[a]pyrene). Biochemistry 2002, 41, 6100-6106. [CrossRef] [PubMed]

74. Huang, X.; Kolbanovskiy, A.; Wu, X.; Zhang, Y.; Wang, Z.; Zhuang, P.; Amin, S.; Geacintov, N.E. Effects of base sequence context on translesion synthesis past a bulky (+)-trans-anti-B[a]P-N ${ }^{2}-\mathrm{dG}$ lesion catalyzed by the Y-family polymerase pol k. Biochemistry 2003, 42, 2456-2466. [CrossRef] [PubMed]

75. Avkin, S.; Goldsmith, M.; Velasco-Miguel, S.; Geacintov, N.; Friedberg, E.C.; Livneh, Z. Quantitative analysis of translesion DNA synthesis across a benzo[a]pyrene-guanine adduct in mammalian cells: The role of DNA polymerase к. J. Biol. Chem. 2004, 279, 53298-53305. [CrossRef] [PubMed]

76. Rechkoblit, O.; Zhang, Y.; Guo, D.; Wang, Z.; Amin, S.; Krzeminsky, J.; Louneva, N.; Geacintov, N.E. trans-Lesion synthesis past bulky benzo[a]pyrene diol epoxide $N^{2}-\mathrm{dG}$ and $N^{6}-\mathrm{dA}$ lesions catalyzed by DNA bypass polymerases. J. Biol. Chem. 2002, 277, 30488-30494. [CrossRef] [PubMed]

77. Wei, S.J.; Chang, R.L.; Wong, C.-Q.; Bhachech, N.; Cui, X.X.; Hennig, E.; Yagi, H.; Sayer, J.M.; Jerina, D.M.; Preston, B.D. Dose-dependent differences in the profile of mutations induced by an ultimate carcinogen from benzo[a]pyrene. Proc. Natl. Acad. Sci. USA 1991, 88, 11227-11230. [CrossRef] [PubMed]

78. Wei, S.C.; Chang, R.L.; Bhachech, N.; Cui, X.X.; Merkler, K.A.; Wong, C.Q.; Hennig, E.; Yagi, H.; Jerina, D.M.; Conney, A.H. Dose-dependent differences in the profile of mutations induced by (+)-7R,8Sdihydroxy-9S,10R-epoxy-7,8,9,10-tetrahydrobenzo[a]pyrene in the coding region of the hypoxanthine (guanine) phosphoribosyltransferase gene in Chinese hamster V-79 cells. Cancer Res. 1993, 53, 3294-3301. [PubMed]

79. Conney, A.H.; Chang, R.L.; Jerina, D.M.; Caroline Wei, S.J. Studies on the metabolism of benzo[a]pyrene and dose-dependent differences in the mutagenic profile of its ultimate carcinogenic metabolite. Drug Metab. Rev. 1994, 26, 125-163. [CrossRef] [PubMed]

80. Hashimoto, K.; Cho, Y.; Yang, I.-Y.; Akagi, J.-I.; Ohashi, E.; Tateishi, S.; De Wind, N.; Hanaoka, F.; Ohmori, H.; Moriya, M. The vital role of polymerase $\zeta$ and REV1 in mutagenic, but not correct, DNA synthesis across benzo $[a]$ pyrene-dG and recruitment of polymerase $\zeta$ by REV1 to replication-stalled site. J. Biol. Chem. 2012, 287, 9613-9622. [CrossRef]

81. Frank, E.G.; Woodgate, R. Increased catalytic activity and altered fidelity of human DNA polymerase $\iota$ in the presence of manganese. J. Biol. Chem. 2007, 282, 24689-24696. [CrossRef] [PubMed]

82. Frank, E.G.; Sayer, J.M.; Kroth, H.; Ohashi, E.; Ohmori, H.; Jerina, D.M.; Woodgate, R. Translesion replication of benzo[a]pyrene and benzo[c]phenanthrene diol epoxide adducts of deoxyadenosine and deoxyguanosine by human DNA polymerase ı. Nucleic Acids Res. 2002, 30, 5284-5292. [CrossRef] [PubMed]

83. Jha, V.; Bian, C.; Xing, G.; Ling, H. Structure and mechanism of error-free replication past the major benzo[a]pyrene adduct by human DNA polymerase k. Nucleic Acids Res. 2016, 44, 4957-4967. [CrossRef] [PubMed]

84. Cosman, M.; De Los Santos, C.; Fiala, R.; Hingerty, B.E.; Singh, S.B.; Ibanez, V.; Margulis, L.A.; Live, D.; Geacintov, N.E.; Broyde, S. Solution conformation of the major adduct between the carcinogen (+)-anti-benzo[a]pyrene diol epoxide and DNA. Proc. Natl. Acad. Sci. USA 1992, 89, 1914-1918. [CrossRef] [PubMed]

85. Feng, B.; Gorin, A.; Hingerty, B.E.; Geacintov, N.E.; Broyde, S.; Patel, D.J. Structural alignment of the (+)-trans-anti-benzo[a]pyrene-dG adduct positioned opposite $\mathrm{dC}$ at a DNA template-primer junction. Biochemistry 1997, 36, 13769-13779. [CrossRef] [PubMed]

86. Donny-Clark, K.; Broyde, S. Influence of local sequence context on damaged base conformation in human DNA polymerase ı: Molecular dynamics studies of nucleotide incorporation opposite a benzo[a]pyrene-derived adenine lesion. Nucleic Acids Res. 2009, 37, 7095-7109. [CrossRef] [PubMed] 
87. Beland, F.A.; Churchwell, M.I.; Von Tungeln, L.S.; Chen, S.; Fu, P.P.; Culp, S.J.; Schoket, B.; Gyorffy, E.; Minárovits, J.; Poirier, M.C. High-performance liquid chromatography electrospray ionization tandem mass spectrometry for the detection and quantitation of benzo[a]pyrene-DNA adducts. Chem. Res. Toxicol. 2005, 18, 1306-1315. [CrossRef] [PubMed]

88. Zhang, Y.; Wu, X.; Rechkoblit, O.; Geacintov, N.E.; Taylor, J.-S.; Wang, Z. Response of human REV1 to different DNA damage: Preferential dCMP insertion opposite the lesion. Nucleic Acids Res. 2002, 30, 1630-1638. [CrossRef] [PubMed]

89. Nelson, J.R.; Gibbs, P.E.M.; Nowicka, A.M.; Hinkle, D.C.; Lawrence, C.W. Evidence for a second function for Saccharomyces cerevisiae Rev1p. Mol. Microbiol. 2000, 37, 549-554. [CrossRef] [PubMed]

90. Guo, C.; Fischhaber, P.L.; Luk-Paszyc, M.J.; Masuda, Y.; Zhou, J.; Kamiya, K.; Kisker, C.; Friedberg, E.C. Mouse Rev1 protein interacts with multiple DNA polymerases involved in translesion DNA synthesis. EMBO J. 2003, 22, 6621-6630. [CrossRef] [PubMed]

91. Ohashi, E.; Murakumo, Y.; Kanjo, N.; Akagi, J.i.; Masutani, C.; Hanaoka, F.; Ohmori, H. Interaction of hREV1 with three human Y-family DNA polymerases. Genes Cells 2004, 9, 523-531. [CrossRef] [PubMed]

92. Tissier, A.; Kannouche, P.; Reck, M.-P.; Lehmann, A.R.; Fuchs, R.P.P.; Cordonnier, A. Co-localization in replication foci and interaction of human Y-family members, DNA polymerase poln and REVl protein. DNA Repair 2004, 3, 1503-1514. [CrossRef] [PubMed]

93. Murakumo, Y.; Ogura, Y.; Ishii, H.; Numata, S.-I.; Ichihara, M.; Croce, C.M.; Fishel, R.; Takahashi, M. Interactions in the error-prone postreplication repair proteins hREV1, hREV3, and hREV7. J. Biol. Chem. 2001, 276, 35644-35651. [CrossRef] [PubMed]

94. Ohashi, E.; Hanafusa, T.; Kamei, K.; Song, I.; Tomida, J.; Hashimoto, H.; Vaziri, C.; Ohmori, H. Identification of a novel REV1-interacting motif necessary for DNA polymerase k function. Genes Cells 2009, 14, 101-111. [CrossRef] [PubMed]

95. Prelich, G.; Tan, C.-K.; Kostura, M.; Mathews, M.B.; So, A.G.; Downey, K.M.; Stillman, B. Functional identity of proliferating cell nuclear antigen and a DNA polymerase-delta auxiliary protein. Nature 1986, 326, 517-520. [CrossRef] [PubMed]

96. Tan, C.-K.; Castillo, C.; So, A.G.; Downey, K.M. An auxiliary protein for DNA polymerase-delta from fetal calf thymus. J. Biol. Chem. 1986, 261, 12310-12316. [PubMed]

97. Maga, G.; Hübscher, U. Proliferating cell nuclear antigen (PCNA): A dancer with many partners. J. Cell Sci. 2003, 116, 3051-3060. [CrossRef] [PubMed]

98. Moldovan, G.-L.; Pfander, B.; Jentsch, S. PCNA, the maestro of the replication fork. Cell 2007, 129, 665-679. [CrossRef] [PubMed]

99. Boehm, E.M.; Gildenberg, M.S.; Washington, M.T. The many roles of PCNA in eukaryotic DNA replication. In The Enzymes; Laurie, S.K., Marcos Túlio, O., Eds.; Academic Press: London, UK, 2016; Volume 39, pp. 231-254.

100. Mailand, N.; Gibbs-Seymour, I.; Bekker-Jensen, S. Regulation of PCNA-protein interactions for genome stability. Nat. Rev. Mol. Cell Biol. 2013, 14, 269-282. [CrossRef] [PubMed]

101. Haracska, L.; Johnson, R.E.; Unk, I.; Phillips, B.; Hurwitz, J.; Prakash, L.; Prakash, S. Physical and functional interactions of human DNA polymerase $\eta$ with PCNA. Mol. Cell. Biol. 2001, 21, 7199-7206. [CrossRef] [PubMed]

102. Haracska, L.; Johnson, R.E.; Unk, I.; Phillips, B.B.; Hurwitz, J.; Prakash, L.; Prakash, S. Targeting of human DNA polymerase $\iota$ to the replication machinery via interaction with PCNA. Proc. Natl. Acad. Sci. USA 2001, 98, 14256-14261. [CrossRef] [PubMed]

103. Haracska, L.; Kondratick, C.M.; Unk, I.; Prakash, S.; Prakash, L. Interaction with PCNA is essential for yeast DNA polymerase $\eta$ function. Mol. Cell 2001, 8, 407-415. [CrossRef]

104. Haracska, L.; Unk, I.; Johnson, R.E.; Phillips, B.B.; Hurwitz, J.; Prakash, L.; Prakash, S. Stimulation of DNA synthesis activity of human DNA polymerase $\mathrm{k}$ by PCNA. Mol. Cell. Biol. 2002, 22, 784-791. [CrossRef] [PubMed]

105. Ohmori, H.; Hanafusa, T.; Ohashi, E.; Vaziri, C. Separate roles of structured and unstructured regions of Y-family DNA polymerases. Adv. Protein Chem. Struct. Biol. 2009, 78, 99-146. [PubMed]

106. Krishna, T.S.R.; Kong, X.-P.; Gary, S.; Burgers, P.M.; Kuriyan, J. Crystal structure of the eukaryotic DNA polymerase processivity factor PCNA. Cell 1994, 79, 1233-1243. [CrossRef] 
107. Gulbis, J.M.; Kelman, Z.; Hurwitz, J.; O’Donnell, M.; Kuriyan, J. Structure of the C-terminal region of p21 WAF1/CIP1 complexed with human PCNA. Cell 1996, 87, 297-306. [CrossRef]

108. Kochaniak, A.B.; Habuchi, S.; Loparo, J.J.; Chang, D.J.; Cimprich, K.A.; Walter, J.C.; van Oijen, A.M. Proliferating cell nuclear antigen uses two distinct modes to move along DNA. J. Biol. Chem. 2009, 284, 17700-17710. [CrossRef] [PubMed]

109. Garg, P.; Stith, C.M.; Majka, J.; Burgers, P.M.J. Proliferating cell nuclear antigen promotes translesion synthesis by DNA polymerase $\zeta$. J. Biol. Chem. 2005, 280, 23446-23450. [CrossRef] [PubMed]

110. Makarova, A.V.; Stodola, J.L.; Burgers, P.M. A four-subunit DNA polymerase $\zeta$ complex containing Pol $\delta$ accessory subunits is essential for PCNA-mediated mutagenesis. Nucleic Acids Res. 2012, 40, 11618-11626. [CrossRef] [PubMed]

111. Garg, P.; Burgers, P.M. Ubiquitinated proliferating cell nuclear antigen activates translesion DNA polymerases $\eta$ and REV1. Proc. Natl. Acad. Sci. USA 2005, 102, 18361-18366. [CrossRef] [PubMed]

112. Bruning, J.B.; Shamoo, Y. Structural and thermodynamic analysis of human PCNA with peptides derived from DNA polymerase- $\delta$ p66 subunit and flap endonuclease-1. Structure 2004, 12, 2209-2219. [CrossRef] [PubMed]

113. Sakurai, S.; Kitano, K.; Yamaguchi, H.; Hamada, K.; Okada, K.; Fukuda, K.; Uchida, M.; Ohtsuka, E.; Morioka, H.; Hakoshima, T. Structural basis for recruitment of human flap endonuclease 1 to PCNA. EMBO J. 2005, 24, 683-693. [CrossRef] [PubMed]

114. Hishiki, A.; Hashimoto, H.; Hanafusa, T.; Kamei, K.; Ohashi, E.; Shimizu, T.; Ohmori, H.; Sato, M. Structural basis for novel interactions between human translesion synthesis polymerases and proliferating cell nuclear antigen. J. Biol. Chem. 2009, 284, 10552-10560. [CrossRef] [PubMed]

115. Guo, C.; Sonoda, E.; Tang, T.-S.; Parker, J.L.; Bielen, A.B.; Takeda, S.; Ulrich, H.D.; Friedberg, E.C. REV1 protein interacts with PCNA: Significance of the REV1 BRCT domain in vitro and in vivo. Mol. Cell 2006, 23, 265-271. [CrossRef] [PubMed]

116. Pustovalova, Y.; Maciejewski, M.W.; Korzhnev, D.M. NMR mapping of PCNA interaction with translesion synthesis DNA polymerase Rev1 mediated by Rev1-BRCT domain. J. Mol. Biol. 2013, 425, 3091-3105. [CrossRef] [PubMed]

117. Sharma, N.M.; Kochenova, O.V.; Shcherbakova, P.V. The non-canonical protein binding site at the monomer-monomer interface of yeast proliferating cell nuclear antigen (PCNA) regulates the Rev1-PCNA interaction and Polढ/Rev1-dependent translesion DNA synthesis. J. Biol. Chem. 2011, 286, 33557-33566. [CrossRef] [PubMed]

118. Boehm, E.M.; Powers, K.T.; Kondratick, C.M.; Spies, M.; Houtman, J.C.D.; Washington, M.T. The proliferating cell nuclear antigen (PCNA)-interacting protein (PIP) motif of DNA polymerase $\eta$ mediates its interaction with the C-terminal domain of Rev1. J. Biol. Chem. 2016, 291, 8735-8744. [CrossRef] [PubMed]

119. Baldeck, N.; Janel-Bintz, R.; Wagner, J.; Tissier, A.; Fuchs, R.P.; Burkovics, P.; Haracska, L.; Despras, E.; Bichara, M.; Chatton, B. FF483-484 motif of human Poln mediates its interaction with the POLD2 subunit of

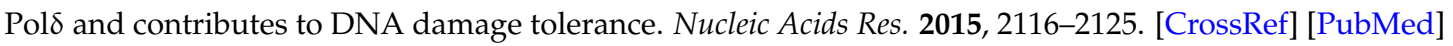

120. Boehm, E.M.; Washington, M.T. R.I.P. to the PIP: PCNA-binding motif no longer considered specific. Bioessays 2016, 38, 1117-1122. [CrossRef] [PubMed]

121. Hedglin, M.; Pandey, B.; Benkovic, S.J. Characterization of human translesion DNA synthesis across a UV-induced DNA lesion. eLife 2016, 5, e19788. [CrossRef] [PubMed]

122. Yang, K.; Weinacht, C.P.; Zhuang, Z. Regulatory role of ubiquitin in eukaryotic DNA translesion synthesis. Biochemistry 2013, 52, 3217-3228. [CrossRef] [PubMed]

123. Kim, W.; Bennett, E.J.; Huttlin, E.L.; Guo, A.; Li, J.; Possemato, A.; Sowa, M.E.; Rad, R.; Rush, J.; Comb, M.J. Systematic and quantitative assessment of the ubiquitin-modified proteome. Mol. Cell 2011, 44, 325-340. [CrossRef] [PubMed]

124. Wagner, S.A.; Beli, P.; Weinert, B.T.; Nielsen, M.L.; Cox, J.; Mann, M.; Choudhary, C. A proteome-wide, quantitative survey of in vivo ubiquitylation sites reveals widespread regulatory roles. Mol. Cell. Proteom. 2011. [CrossRef] [PubMed]

125. Bienko, M.; Green, C.M.; Crosetto, N.; Rudolf, F.; Zapart, G.; Coull, B.; Kannouche, P.; Wider, G.; Peter, M.; Lehmann, A.R. Ubiquitin-binding domains in Y-family polymerases regulate translesion synthesis. Science 2005, 310, 1821-1824. [CrossRef] [PubMed] 
126. Freudenthal, B.D.; Gakhar, L.; Ramaswamy, S.; Washington, M.T. Structure of monoubiquitinated PCNA and implications for translesion synthesis and DNA polymerase exchange. Nat. Struct. Mol. Biol. 2010, 17, 479-484. [CrossRef] [PubMed]

127. Dieckman, L.M.; Washington, M.T. PCNA trimer instability inhibits translesion synthesis by DNA polymerase $\eta$ and by DNA polymerase $\delta$. DNA Repair 2013, 12, 367-376. [CrossRef] [PubMed]

128. Zhuang, Z.; Johnson, R.E.; Haracska, L.; Prakash, L.; Prakash, S.; Benkovic, S.J. Regulation of polymerase exchange between Pol $\eta$ and Pol $\delta$ by monoubiquitination of PCNA and the movement of DNA polymerase holoenzyme. Proc. Natl. Acad. Sci. USA 2008, 105, 5361-5366. [CrossRef] [PubMed]

129. Hoege, C.; Pfander, B.; Moldovan, G.-L.; Pyrowolakis, G.; Jentsch, S. RAD6-dependent DNA repair is linked to modification of PCNA by ubiquitin and SUMO. Nature 2002, 419, 135-141. [CrossRef] [PubMed]

130. Stelter, P.; Ulrich, H.D. Control of spontaneous and damage-induced mutagenesis by SUMO and ubiquitin conjugation. Nature 2003, 425, 188-191. [CrossRef] [PubMed]

131. Kannouche, P.L.; Wing, J.; Lehmann, A.R. Interaction of human DNA polymerase $\eta$ with monoubiquitinated PCNA: A possible mechanism for the polymerase switch in response to DNA damage. Mol. Cell 2004, 14, 491-500. [CrossRef]

132. Watanabe, K.; Tateishi, S.; Kawasuji, M.; Tsurimoto, T.; Inoue, H.; Yamaizumi, M. Rad18 guides poln to replication stalling sites through physical interaction and PCNA monoubiquitination. EMBO J. 2004, 23, 3886-3896. [CrossRef] [PubMed]

133. Despras, E.; Delrieu, N.; Garandeau, C.; Ahmed-Seghir, S.; Kannouche, P.L. Regulation of the specialized DNA polymerase eta: Revisiting the biological relevance of its PCNA-and ubiquitin-binding motifs. Environ. Mol. Mutagen. 2012, 53, 752-765. [CrossRef] [PubMed]

134. Acharya, N.; Yoon, J.-H.; Gali, H.; Unk, I.; Haracska, L.; Johnson, R.E.; Hurwitz, J.; Prakash, L.; Prakash, S. Roles of PCNA-binding and ubiquitin-binding domains in human DNA polymerase $\eta$ in translesion DNA synthesis. Proc. Natl. Acad. Sci. USA 2008, 105, 17724-17729. [CrossRef] [PubMed]

135. Sabbioneda, S.; Green, C.M.; Bienko, M.; Kannouche, P.; Dikic, I.; Lehmann, A.R. Ubiquitin-binding motif of human DNA polymerase $\eta$ is required for correct localization. Proc. Natl. Acad. Sci. USA 2009, 106. [CrossRef] [PubMed]

136. Sabbioneda, S.; Gourdin, A.M.; Green, C.M.; Zotter, A.; Giglia-Mari, G.; Houtsmuller, A.; Vermeulen, W.; Lehmann, A.R. Effect of proliferating cell nuclear antigen ubiquitination and chromatin structure on the dynamic properties of the Y-family DNA polymerases. Mol. Biol. Cell 2008, 19, 5193-5202. [CrossRef] [PubMed]

137. Göhler, T.; Sabbioneda, S.; Green, C.M.; Lehmann, A.R. ATR-mediated phosphorylation of DNA polymerase $\eta$ is needed for efficient recovery from UV damage. J. Cell Biol. 2011, 192, 219-227. [CrossRef] [PubMed]

138. Hendel, A.; Krijger, P.H.L.; Diamant, N.; Goren, Z.; Langerak, P.; Kim, J.; Reißner, T.; Lee, K.-y.; Geacintov, N.E.; Carell, T. PCNA ubiquitination is important, but not essential for translesion DNA synthesis in mammalian cells. PLoS Genet. 2011, 7, e1002262. [CrossRef] [PubMed]

139. Langerak, P.; Nygren, A.O.H.; Krijger, P.H.L.; van den Berk, P.C.M.; Jacobs, H. A/T mutagenesis in hypermutated immunoglobulin genes strongly depends on PCNA ${ }^{\mathrm{K} 164}$ modification. J. Exp. Med. 2007, 204, 1989-1998. [CrossRef] [PubMed]

140. Szüts, D.; Marcus, A.P.; Himoto, M.; Iwai, S.; Sale, J.E. REV1 restrains DNA polymerase $\zeta$ to ensure frame fidelity during translesion synthesis of UV photoproducts in vivo. Nucleic Acids Res. 2008, 36, 6767-6780. [CrossRef] [PubMed]

141. Edmunds, C.E.; Simpson, L.J.; Sale, J.E. PCNA ubiquitination and REV1 define temporally distinct mechanisms for controlling translesion synthesis in the avian cell line DT40. Mol. Cell 2008, 30, 519-529. [CrossRef] [PubMed]

142. Lau, W.C.; Li, Y.; Zhang, Q.; Huen, M.S. Molecular architecture of the Ub-PCNA/Pol $\eta$ complex bound to DNA. Sci. Rep. 2015. [CrossRef] [PubMed]

143. Prindle, M.J.; Loeb, L.A. DNA polymerase delta in DNA replication and genome maintenance. Environ. Mol. Mutagen. 2012, 53, 666-682. [CrossRef] [PubMed]

144. Netz, D.J.A.; Stith, C.M.; Stümpfig, M.; Köpf, G.; Vogel, D.; Genau, H.M.; Stodola, J.L.; Lill, R.; Burgers, P.M.J.; Pierik, A.J. Eukaryotic DNA polymerases require an iron-sulfur cluster for the formation of active complexes. Nat. Chem. Biol. 2012, 8, 125-132. [CrossRef] [PubMed] 
145. Nair, D.T.; Johnson, R.E.; Prakash, L.; Prakash, S.; Aggarwal, A.K. Rev1 employs a novel mechanism of DNA synthesis using a protein template. Science 2005, 309, 2219-2222. [CrossRef] [PubMed]

146. Haracska, L.; Unk, I.; Johnson, R.E.; Johansson, E.; Burgers, P.M.J.; Prakash, S.; Prakash, L. Roles of yeast DNA polymerases $\delta$ and $\zeta$ and of Rev1 in the bypass of abasic sites. Genes Dev. 2001, 15, 945-954. [CrossRef] [PubMed]

147. Ross, A.-L.; Simpson, L.J.; Sale, J.E. Vertebrate DNA damage tolerance requires the C-terminus but not BRCT or transferase domains of REV1. Nucleic Acids Res. 2005, 33, 1280-1289. [CrossRef] [PubMed]

148. Baranovskiy, A.G.; Lada, A.G.; Siebler, H.M.; Zhang, Y.; Pavlov, Y.I.; Tahirov, T.H. DNA polymerase $\delta$ and $\zeta$ switch by sharing accessory subunits of DNA polymerase $\delta$. J. Biol. Chem. 2012, 287, 17281-17287. [CrossRef] [PubMed]

149. Johnson, R.E.; Prakash, L.; Prakash, S. Pol31 and Pol32 subunits of yeast DNA polymerase $\delta$ are also essential subunits of DNA polymerase $\zeta$. Proc. Natl. Acad. Sci. USA 2012, 109, 12455-12460. [CrossRef] [PubMed]

150. Pustovalova, Y.; Magalhães, M.T.Q.; D’Souza, S.; Rizzo, A.A.; Korza, G.; Walker, G.C.; Korzhnev, D.M. Interaction between the Rev1 C-terminal domain and the PolD3 subunit of Pol $\zeta$ suggests a mechanism of polymerase exchange upon Rev1/Polל-dependent translesion synthesis. Biochemistry 2016, 55, 2043-2053. [CrossRef] [PubMed]

151. Gabel, S.A.; DeRose, E.F.; London, R.E. XRCC1 interaction with the REV1 C-terminal domain suggests a role in post replication repair. DNA Repair 2013, 12, 1105-1113. [CrossRef] [PubMed]

152. Xu, X.; Lin, A.; Zhou, C.; Blackwell, S.R.; Zhang, Y.; Wang, Z.; Feng, Q.; Guan, R.; Hanna, M.D.; Chen, Z.; et al. Involvement of budding yeast Rad5 in translesion DNA synthesis through physical interaction with Rev1. Nucleic Acids Res. 2016, 44, 5231-5245. [CrossRef] [PubMed]

153. Pozhidaeva, A.; Pustovalova, Y.; D’Souza, S.; Bezsonova, I.; Walker, G.C.; Korzhnev, D.M. NMR structure and dynamics of the C-terminal domain from human Rev1 and its complex with Rev1 interacting region of DNA polymerase $\eta$. Biochemistry 2012, 51, 5506-5520. [CrossRef] [PubMed]

154. Wojtaszek, J.; Liu, J.; D'Souza, S.; Wang, S.; Xue, Y.; Walker, G.C.; Zhou, P. Multifaceted recognition of vertebrate Rev1 by translesion polymerases $\zeta$ and $\kappa$. J. Biol. Chem. 2012, 287, 26400-26408. [CrossRef] [PubMed]

155. Livneh, Z.; Shachar, S. Multiple two-polymerase mechanisms in mammalian translesion DNA synthesis. Cell Cycle 2010, 9, 729-735. [CrossRef] [PubMed]

156. Yoon, J.-H.; Prakash, L.; Prakash, S. Error-free replicative bypass of (6-4) photoproducts by DNA polymerase $\zeta$ in mouse and human cells. Genes Dev. 2010, 24, 123-128. [CrossRef] [PubMed]

157. Wojtaszek, J.; Lee, C.-J.; D'Souza, S.; Minesinger, B.; Kim, H.; D'Andrea, A.D.; Walker, G.C.; Zhou, P. Structural basis of Rev1-mediated assembly of a quaternary vertebrate translesion polymerase complex consisting of Rev1, heterodimeric polymerase (Pol) $\zeta$, and Pol k. J. Biol. Chem. 2012, 287, 33836-33846. [CrossRef] [PubMed]

158. Xie, W.; Yang, X.; Xu, M.; Jiang, T. Structural insights into the assembly of human translesion polymerase complexes. Protein Cell 2012, 3, 864-874. [CrossRef] [PubMed]

159. Kikuchi, S.; Hara, K.; Shimizu, T.; Sato, M.; Hashimoto, H. Structural basis of recruitment of DNA polymerase $\zeta$ by interaction between REV1 and REV7 proteins. J. Biol. Chem. 2012, 287, 33847-33852. [CrossRef] [PubMed]

160. Boehm, E.M.; Spies, M.; Washington, M.T. PCNA tool belts and polymerase bridges form during translesion synthesis. Nucleic Acids Res. 2016, 44, 8250-8260. [CrossRef] [PubMed]

161. Andersen, P.L.; Xu, F.; Ziola, B.; McGregor, W.G.; Xiao, W. Sequential assembly of translesion DNA polymerases at UV-induced DNA damage sites. Mol. Biol. Cell 2011, 22, 2373-2383. [CrossRef] [PubMed]

162. Akagi, J.-I.; Masutani, C.; Kataoka, Y.; Kan, T.; Ohashi, E.; Mori, T.; Ohmori, H.; Hanaoka, F. Interaction with DNA polymerase $\eta$ is required for nuclear accumulation of REV1 and suppression of spontaneous mutations in human cells. DNA Repair 2009, 8, 585-599. [CrossRef] [PubMed]

163. Lee, Y.-S.; Gregory, M.T.; Yang, W. Human Pol $\zeta$ purified with accessory subunits is active in translesion DNA synthesis and complements Pol $\eta$ in cisplatin bypass. Proc. Natl. Acad. Sci. USA 2014, 111, 2954-2959. [CrossRef] [PubMed]

164. Johansson, E.; Garg, P.; Burgers, P.M.J. The Pol32 subunit of DNA polymerase $\delta$ contains separable domains for processive replication and proliferating cell nuclear antigen (PCNA) binding. J. Biol. Chem. 2004, 279, 1907-1915. [CrossRef] [PubMed] 
165. Gómez-Llorente, Y.; Malik, R.; Jain, R.; Choudhury, J.R.; Johnson, R.E.; Prakash, L.; Prakash, S.; Ubarretxena-Belandia, I.; Aggarwal, A.K. The architecture of yeast DNA polymerase $\zeta$. Cell reports 2013, 5, 79-86. [CrossRef] [PubMed]

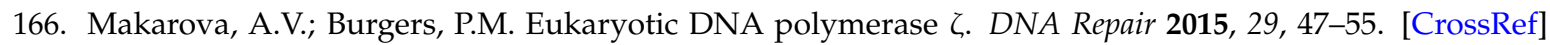
[PubMed]

167. Zhang, S.; Zhou, Y.; Trusa, S.; Meng, X.; Lee, E.Y.C.; Lee, M.Y.W.T. A novel DNA damage response: Rapid degradation of the p12 subunit of DNA polymerase $\delta$. J. Biol. Chem. 2007, 282, 15330-15340. [CrossRef] [PubMed]

168. Murga, M.; Lecona, E.; Kamileri, I.; Díaz, M.; Lugli, N.; Sotiriou, S.K.; Anton, M.E.; Méndez, J.; Halazonetis, T.D.; Fernandez-Capetillo, O. POLD3 is haploinsufficient for DNA replication in mice. Mol. Cell 2016, 63, 877-883. [CrossRef] [PubMed]

169. Stepchenkova, E.I.; Tarakhovskaya, E.R.; Siebler, H.M.; Pavlov, Y.I. Defect of Fe-S cluster binding by DNA polymerase $\delta$ in yeast suppresses UV-induced mutagenesis, but enhances DNA polymerase $\zeta$-Dependent spontaneous mutagenesis. DNA Repair 2016. [CrossRef]

170. Little, J.W.; Mount, D.W. The SOS regulatory system of Escherichia coli. Cell 1982, 29, 11-22. [CrossRef]

171. Goodman, M.F.; McDonald, J.P.; Jaszczur, M.M.; Woodgate, R. Insights into the complex levels of regulation imposed on Escherichia coli DNA polymerase V. DNA Repair 2016, 44, 42-50. [CrossRef] [PubMed]

172. Wiltrout, M.E.; Walker, G.C. Proteasomal regulation of the mutagenic translesion DNA polymerase, Saccharomyces cerevisiae Rev1. DNA Repair 2011, 10, 169-175. [CrossRef] [PubMed]

173. Pabla, R.; Rozario, D.; Siede, W. Regulation of Saccharomyces cerevisiae DNA polymerase $\eta$ transcript and protein. Radiat. Environ. Biophys. 2008, 47, 157-168. [CrossRef] [PubMed]

174. Waters, L.S.; Walker, G.C. The critical mutagenic translesion DNA polymerase Rev1 is highly expressed during $\mathrm{G}_{2} / \mathrm{M}$ phase rather than $\mathrm{S}$ phase. Proc. Natl. Acad. Sci. USA 2006, 103, 8971-8976. [CrossRef] [PubMed]

175. Plachta, M.; Halas, A.; McIntyre, J.; Sledziewska-Gojska, E. The steady-state level and stability of TLS polymerase eta are cell cycle dependent in the yeast S. cerevisiae. DNA Repair 2015, 29, 147-153. [CrossRef] [PubMed]

176. Uchiyama, M.; Terunuma, J.; Hanaoka, F. The protein level of Rev1, a TLS polymerase in fission yeast, is strictly regulated during the cell cycle and after DNA damage. PLoS ONE 2015, 10, e0130000. [CrossRef] [PubMed]

177. King, N.M.; Nikolaishvili-Feinberg, N.; Bryant, M.F.; Luche, D.D.; Heffernan, T.P.; Simpson, D.A.; Hanaoka, F.; Kaufmann, W.K.; Cordeiro-Stone, M. Overproduction of DNA polymerase eta does not raise the spontaneous mutation rate in diploid human fibroblasts. DNA Repair 2005, 4, 714-724. [CrossRef] [PubMed]

178. Thakur, M.; Wernick, M.; Collins, C.; Limoli, C.L.; Crowley, E.; Cleaver, J.E. DNA polymerase $\eta$ undergoes alternative splicing, protects against UV sensitivity and apoptosis, and suppresses Mre11-dependent recombination. Genes Chromosomes Cancer 2001, 32, 222-235. [CrossRef] [PubMed]

179. Qi, H.; Zhu, H.; Lou, M.; Fan, Y.; Liu, H.; Shen, J.; Li, Z.; Lv, X.; Shan, J.; Zhu, L. Interferon regulatory factor 1 transactivates expression of human DNA polymerase $\eta$ in response to carcinogen $N$-methyl- $N^{\prime}$-nitro-N-nitrosoguanidine. J. Biol. Chem. 2012, 287, 12622-12633. [CrossRef] [PubMed]

180. Yu, S.-L.; Johnson, R.E.; Prakash, S.; Prakash, L. Requirement of DNA polymerase $\eta$ for error-free bypass of UV-induced CC and TC photoproducts. Mol. Cell. Biol. 2001, 21, 185-188. [CrossRef] [PubMed]

181. Haruta, N.; Kubota, Y.; Hishida, T. Chronic low-dose ultraviolet-induced mutagenesis in nucleotide excision repair-deficient cells. Nucleic Acids Res. 2012, 40, 8406-8415. [CrossRef] [PubMed]

182. Pavlov, Y.I.; Nguyen, D.; Kunkel, T.A. Mutator effects of overproducing DNA polymerase $\eta(\operatorname{Rad} 30)$ and its catalytically inactive variant in yeast. Mutat. Res. Fundam. Mol. Mech. Mutag. 2001, 478, 129-139. [CrossRef]

183. McIntyre, J.; Woodgate, R. Regulation of translesion DNA synthesis: Posttranslational modification of lysine residues in key proteins. DNA Repair 2015, 29, 166-179. [CrossRef] [PubMed]

184. García-Rodríguez, N.; Wong, R.P.; Ulrich, H.D. Functions of ubiquitin and SUMO in DNA replication and replication stress. Front. Genet. 2016. [CrossRef] [PubMed]

185. Jung, Y.-S.; Liu, G.; Chen, X. Pirh2 E3 ubiquitin ligase targets DNA polymerase eta for 20S proteasomal degradation. Mol. Cell. Biol. 2010, 30, 1041-1048. [CrossRef] [PubMed]

186. Jung, Y.-S.; Hakem, A.; Hakem, R.; Chen, X. Pirh2 E3 ubiquitin ligase monoubiquitinates DNA polymerase eta to suppress translesion DNA synthesis. Mol. Cell. Biol. 2011, 31, 3997-4006. [CrossRef] [PubMed] 
187. Jung, Y.-S.; Qian, Y.; Chen, X. DNA polymerase eta is targeted by Mdm2 for polyubiquitination and proteasomal degradation in response to ultraviolet irradiation. DNA Repair 2012, 11, 177-184. [CrossRef] [PubMed]

188. Wallace, H.A.; Merkle, J.A.; Yu, M.C.; Berg, T.G.; Lee, E.; Bosco, G.; Lee, L.A. TRIP/NOPO E3 ubiquitin ligase promotes ubiquitylation of DNA polymerase $\eta$. Development 2014, 141, 1332-1341. [CrossRef] [PubMed]

189. Havens, C.G.; Walter, J.C. Mechanism of CRL4 ${ }^{\text {Cdt2 }}$, a PCNA-dependent E3 ubiquitin ligase. Genes Dev. 2011, 25, 1568-1582. [CrossRef] [PubMed]

190. Higa, L.A.A.; Mihaylov, I.S.; Banks, D.P.; Zheng, J.; Zhang, H. Radiation-mediated proteolysis of CDT1 by CUL4-ROC1 and CSN complexes constitutes a new checkpoint. Nat. Cell Biol. 2003, 5, 1008-1015. [CrossRef] [PubMed]

191. Shiomi, Y.; Hayashi, A.; Ishii, T.; Shinmyozu, K.; Nakayama, J.-I.; Sugasawa, K.; Nishitani, H. Two different replication factor $\mathrm{C}$ proteins, Ctf18 and RFC1, separately control PCNA-CRL4 ${ }^{\mathrm{Cdt} 2}$-mediated Cdt1 proteolysis during S phase and following UV irradiation. Mol. Cell. Biol. 2012, 32, 2279-2288. [CrossRef] [PubMed]

192. Kim, S.-H.; Michael, W.M. Regulated proteolysis of DNA polymerase $\eta$ during the DNA-damage response in C. elegans. Mol. Cell 2008, 32, 757-766. [CrossRef] [PubMed]

193. Havens, C.G.; Walter, J.C. Docking of a specialized PIP box onto chromatin-bound PCNA creates a degron for the ubiquitin ligase CRL4 ${ }^{\text {Cdt2 }}$. Mol. Cell 2009, 35, 93-104. [CrossRef] [PubMed]

194. Michishita, M.; Morimoto, A.; Ishii, T.; Komori, H.; Shiomi, Y.; Higuchi, Y.; Nishitani, H. Positively charged residues located downstream of PIP box, together with TD amino acids within PIP box, are important for CRL4 ${ }^{\mathrm{Cdt} 2}$-mediated proteolysis. Genes Cells 2011, 16, 12-22. [CrossRef] [PubMed]

195. Tsanov, N.; Kermi, C.; Coulombe, P.; van der Laan, S.; Hodroj, D.; Maiorano, D. PIP degron proteins, substrates of CRL4 ${ }^{\mathrm{Cdt} 2}$, and not PIP boxes, interfere with DNA polymerase $\eta$ and $\mathrm{k}$ focus formation on UV damage. Nucleic Acids Res. 2014, 42, 3692-3706. [CrossRef] [PubMed]

196. Li, H.; Xie, B.; Zhou, Y.; Rahmeh, A.; Trusa, S.; Zhang, S.; Gao, Y.; Lee, E.Y.; Lee, M.Y. Functional roles of p12, the fourth subunit of human DNA polymerase $\delta$. J. Biol. Chem. 2006, 281, 14748-14755. [CrossRef] [PubMed]

197. Meng, X.; Zhou, Y.; Lee, E.Y.C.; Lee, M.Y.W.T.; Frick, D.N. The p12 subunit of human polymerase $\delta$ modulates the rate and fidelity of DNA synthesis. Biochemistry 2010, 49, 3545-3554. [CrossRef] [PubMed]

198. Meng, X.; Zhou, Y.; Zhang, S.; Lee, E.Y.C.; Frick, D.N.; Lee, M.Y.W.T. DNA damage alters DNA polymerase $\delta$ to a form that exhibits increased discrimination against modified template bases and mismatched primers. Nucleic Acids Res. 2009, 37, 647-657. [CrossRef] [PubMed]

199. Zhao, H.; Zhang, S.; Xu, D.; Lee, M.Y.W.T.; Zhang, Z.; Lee, E.Y.C.; Darzynkiewicz, Z. Expression of the p12 subunit of human DNA polymerase $\delta$ (Pol $\delta$ ), CDK inhibitor p21WAF1, Cdt1, cyclin A, PCNA and Ki-67 in relation to DNA replication in individual cells. Cell Cycle 2014, 13, 3529-3540. [CrossRef] [PubMed]

200. Lee, M.Y.W.T.; Zhang, S.; Hua Lin, S.; Wang, X.; Darzynkiewicz, Z.; Zhang, Z.; Lee, E. The tail that wags the dog: P12, the smallest subunit of DNA polymerase $\delta$, is degraded by ubiquitin ligases in response to DNA damage and during cell cycle progression. Cell Cycle 2014, 13, 23-31. [CrossRef] [PubMed]

201. Darzynkiewicz, Z.; Zhao, H.; Zhang, S.; Marietta, Y.W.T.L.; Ernest, Y.C.L.; Zhang, Z. Initiation and termination of DNA replication during $S$ phase in relation to cyclins D1, E and A, p21WAF1, Cdt1 and the p12 subunit of DNA polymerase $\delta$ revealed in individual cells by cytometry. Oncotarget 2015, 6, 11735-11750. [CrossRef] [PubMed]

202. Hedglin, M.; Pandey, B.; Benkovic, S.J. Stability of the human polymerase $\delta$ holoenzyme and its implications in lagging strand DNA synthesis. Proc. Natl. Acad. Sci. USA 2016, 113, E1777-E1786. [CrossRef] [PubMed]

203. Tsurimoto, T.; Stillman, B. Replication factors required for SV40 DNA replication in vitro. II. Switching of DNA polymerase alpha and delta during initiation of leading and lagging strand synthesis. J. Biol. Chem. 1991, 266, 1961-1968. [PubMed]

204. Yurieva, O.; O'Donnell, M. Reconstitution of a eukaryotic replisome reveals the mechanism of asymmetric distribution of DNA polymerases. Nucleus 2016, 7, 360-368. [CrossRef] [PubMed]

(C) 2017 by the authors; licensee MDPI, Basel, Switzerland. This article is an open access article distributed under the terms and conditions of the Creative Commons Attribution (CC-BY) license (http:/ / creativecommons.org/licenses/by/4.0/). 